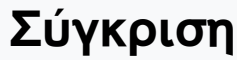

Tóp. 16 (2005)

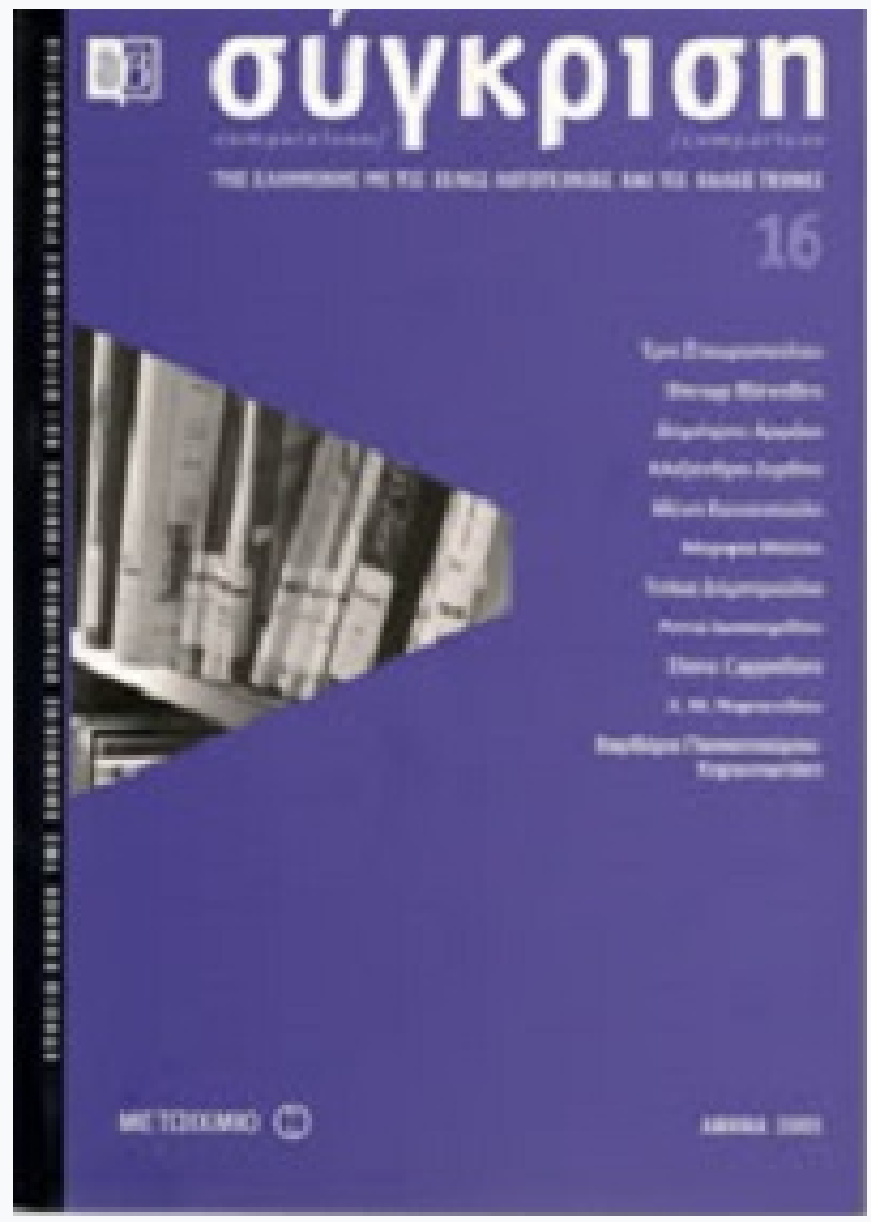

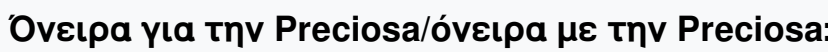

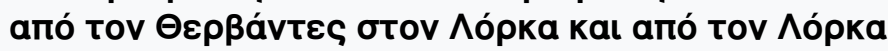

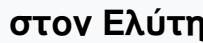

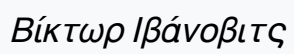

doi: $\underline{10.12681 / \text { comparison.10086 }}$

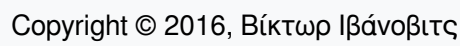

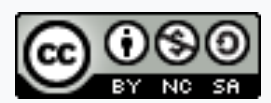

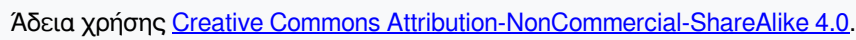

\section{Bıß入ıорафıкń avaџорá:}

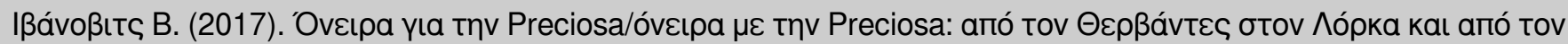

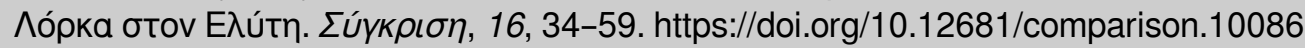




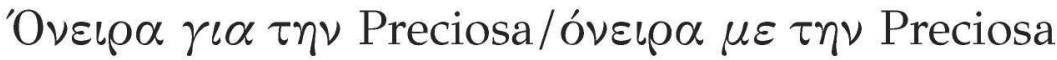

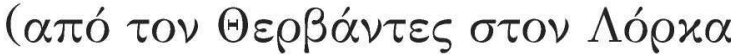

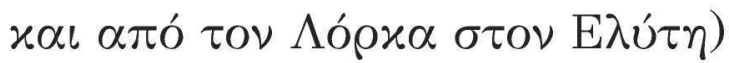

\begin{abstract}
$\boldsymbol{\Sigma}$

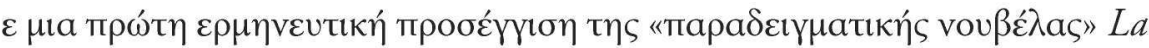

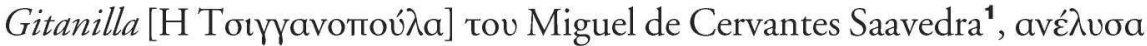

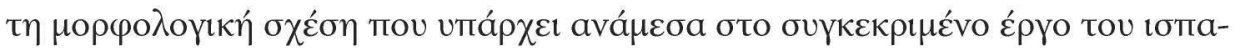

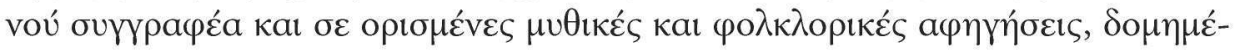

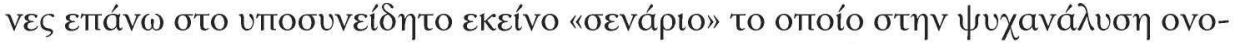

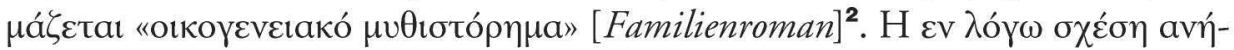

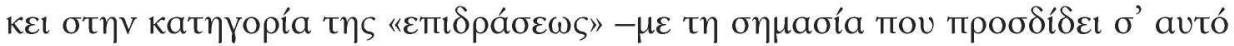

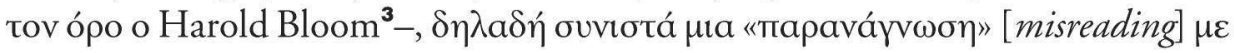

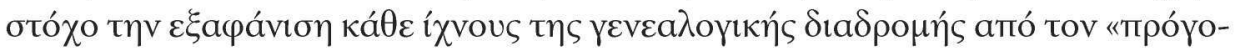

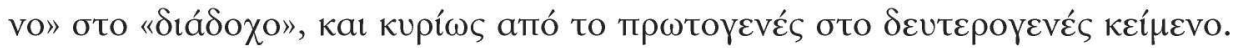

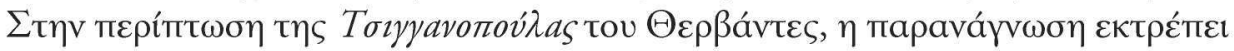

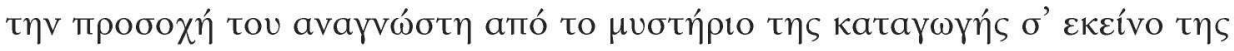

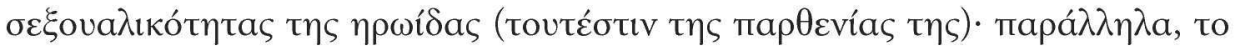

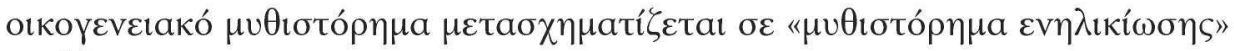

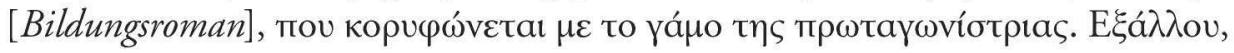

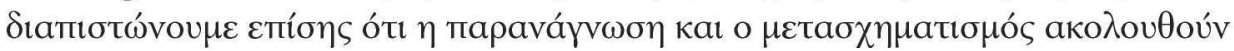

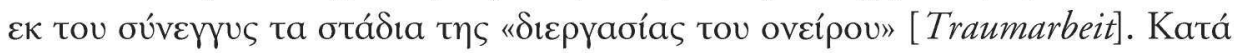

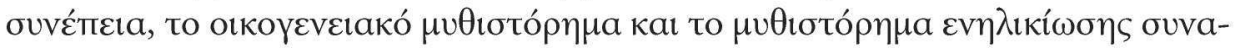

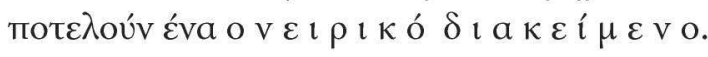

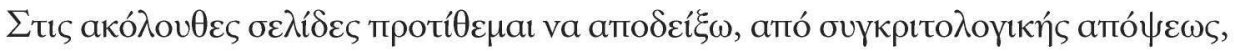

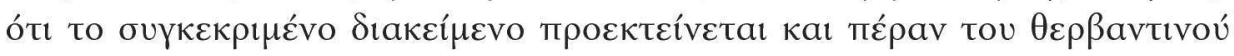

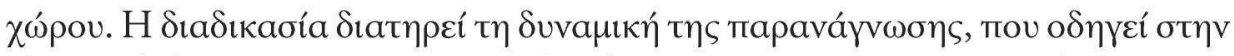

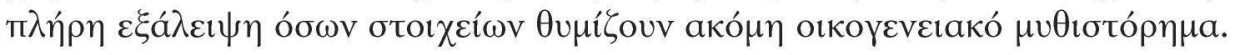

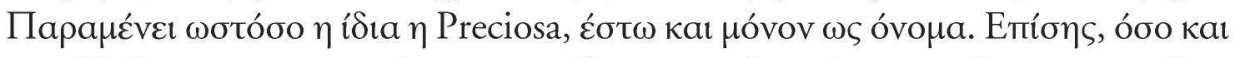

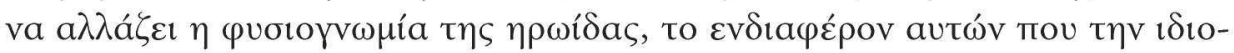

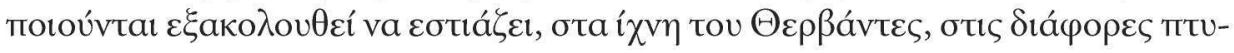

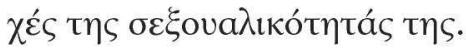




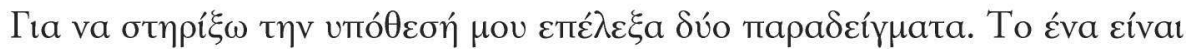

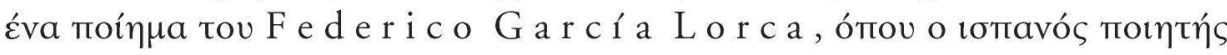

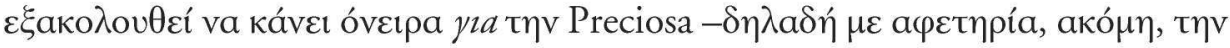

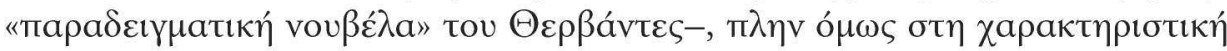

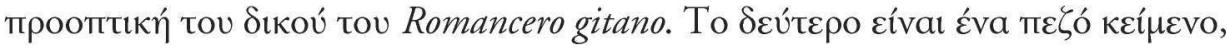

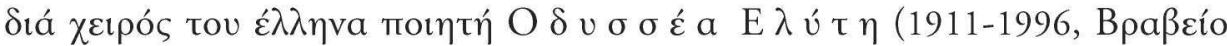

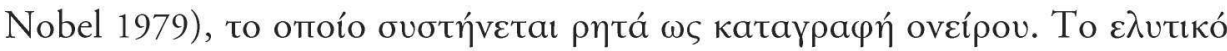

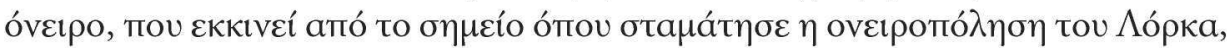

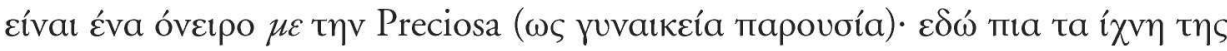

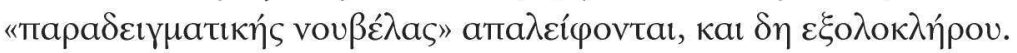

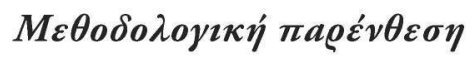

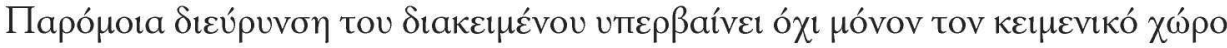

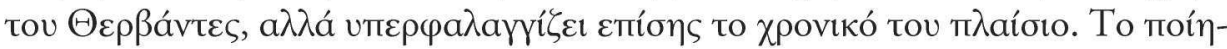

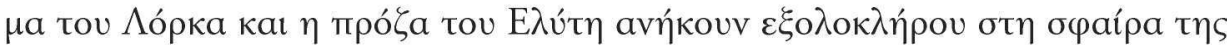

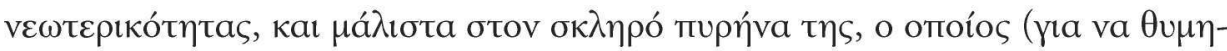

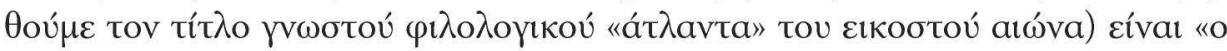

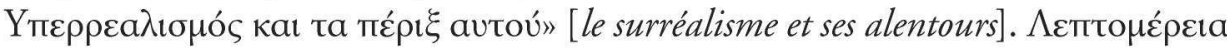

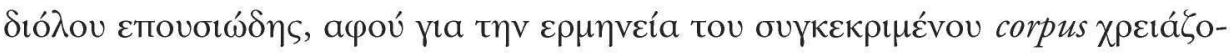

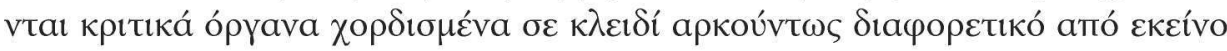

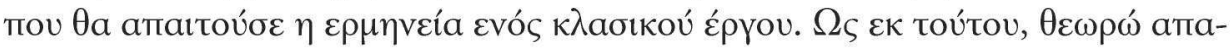

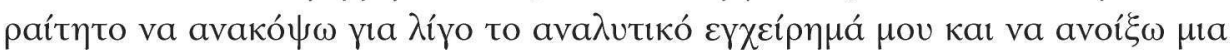

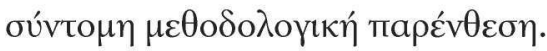

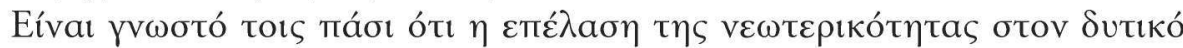

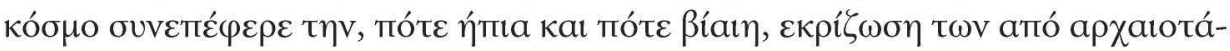

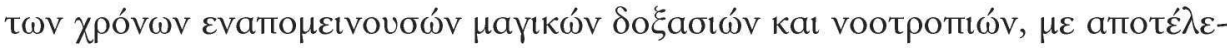

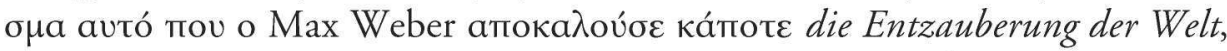

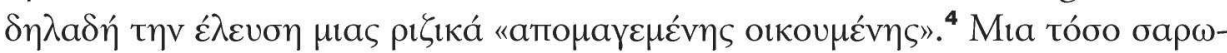

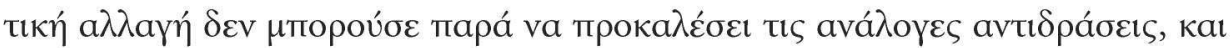

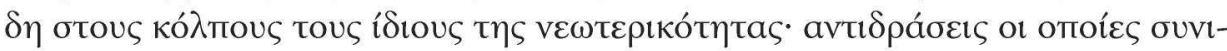

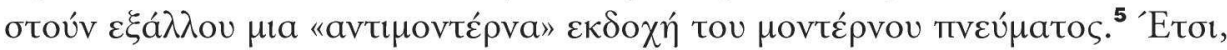

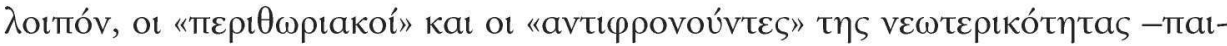

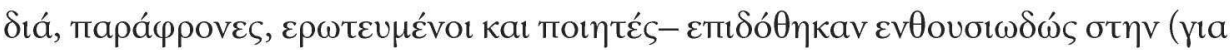

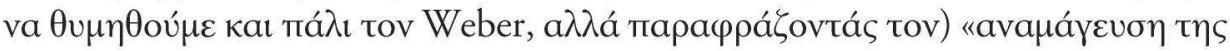

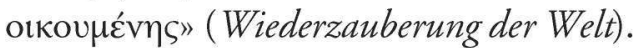

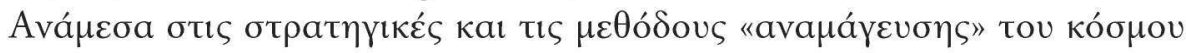




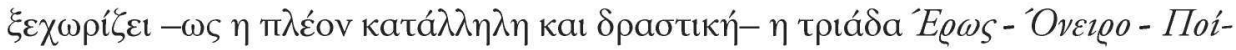

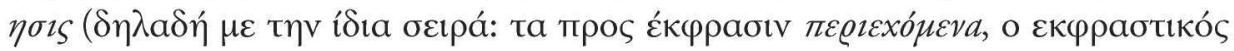

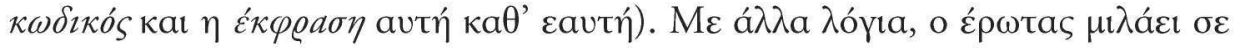

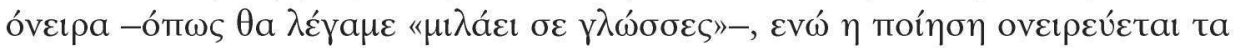

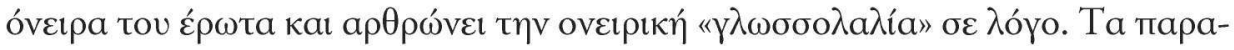

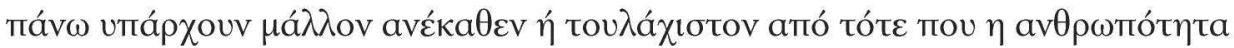

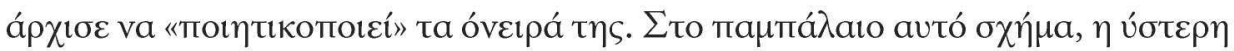

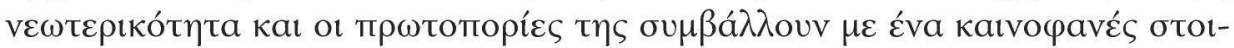

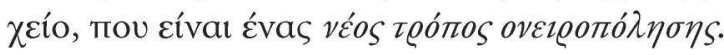

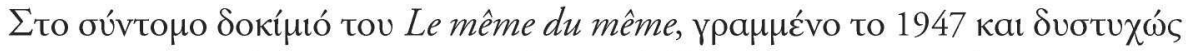

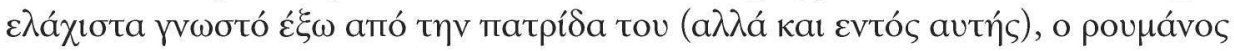

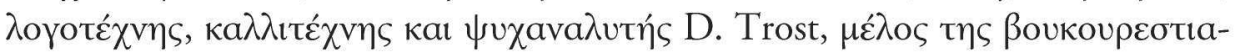

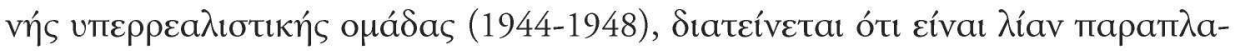

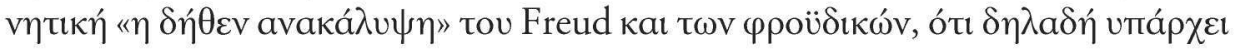

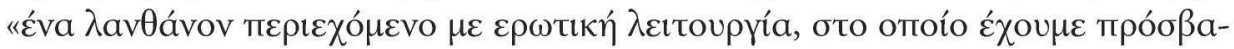

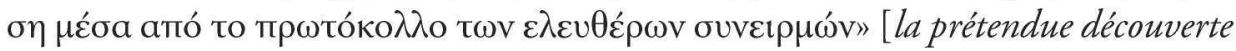
d'un contenu latent à fonction érotique, auquel on advient par le rituel de l'

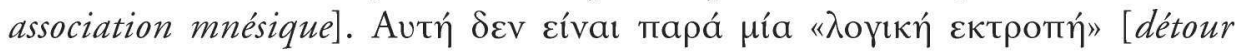

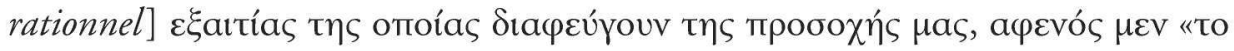

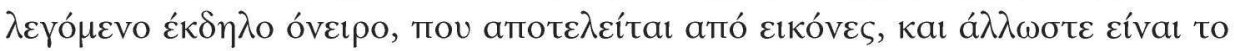

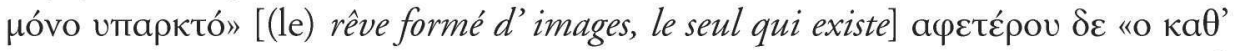

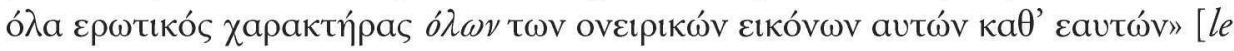

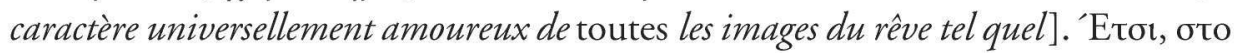

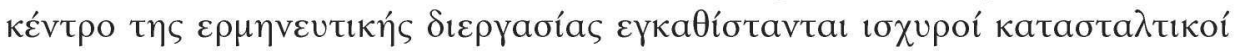

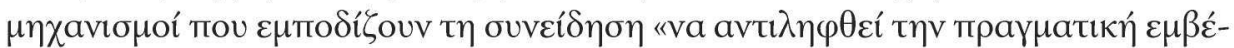

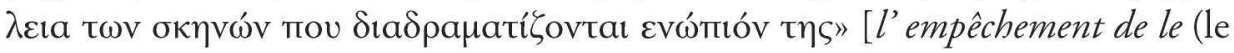

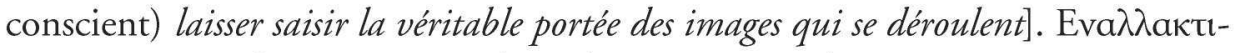

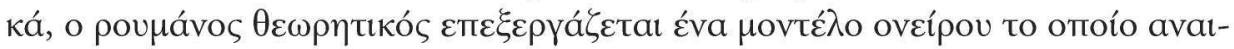

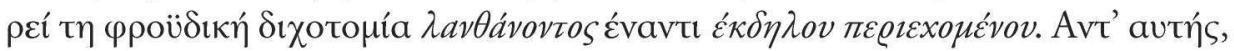

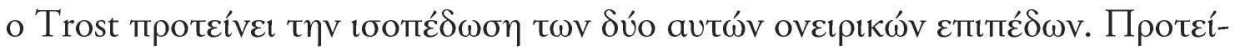

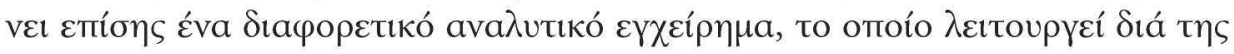

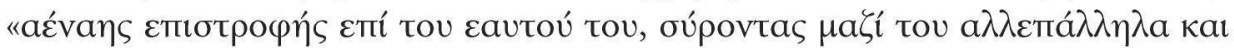

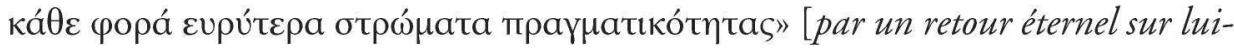
même, qui entraîne successivement des couches de plus en plus vastes de réalité]. 'Evas

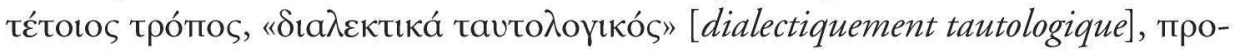

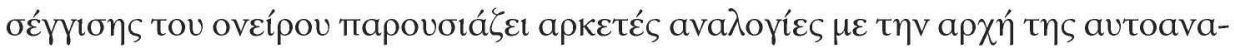

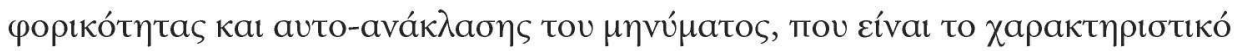




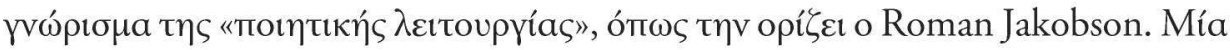

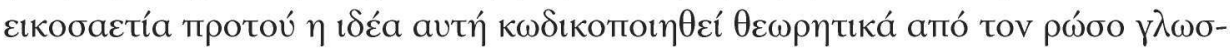

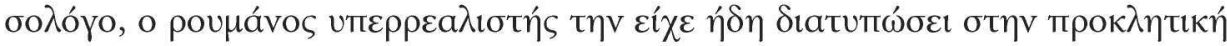

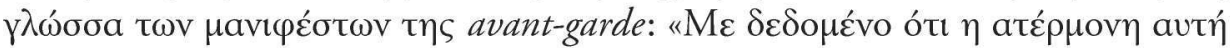

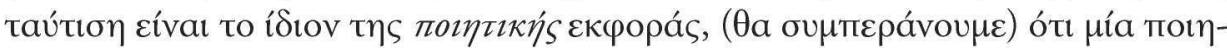

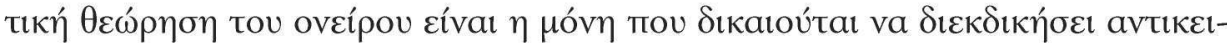

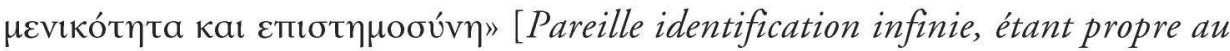
mode poétique, seule la considération poétique du rêve est objective et scientifique]. ${ }^{6}$

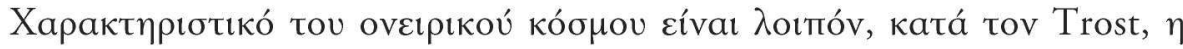

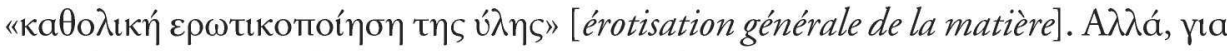

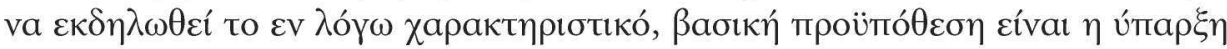

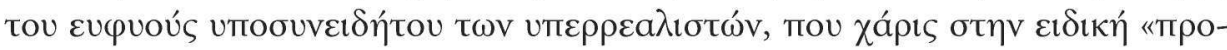

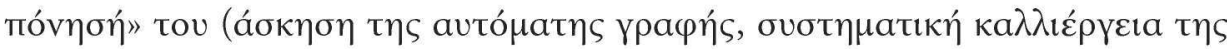

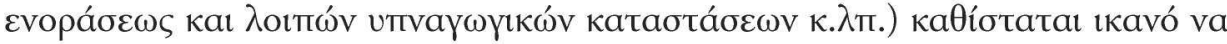

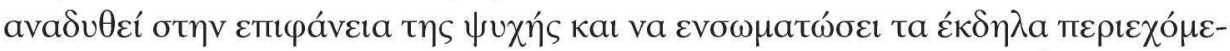

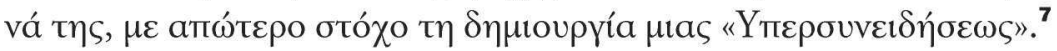

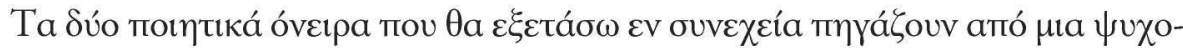

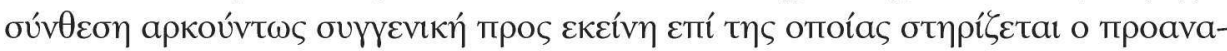

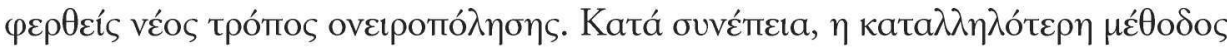

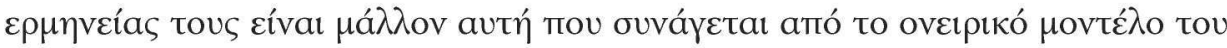

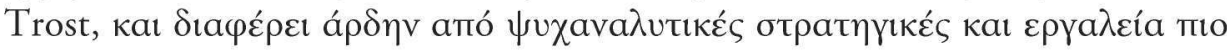

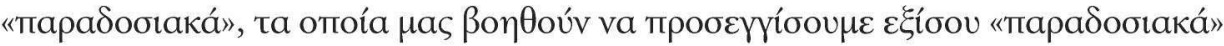

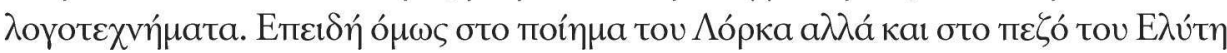

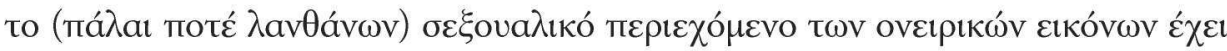

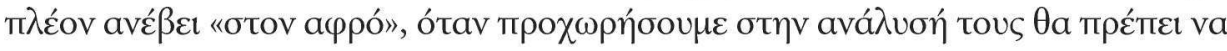

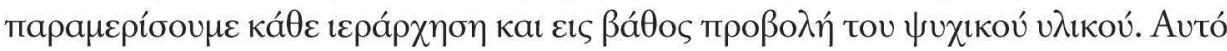

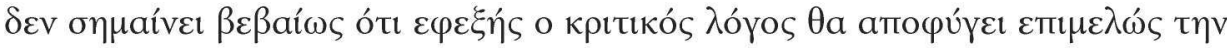

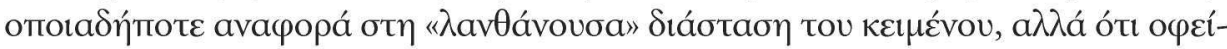

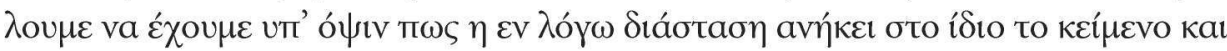

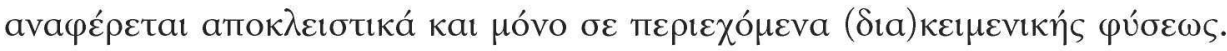

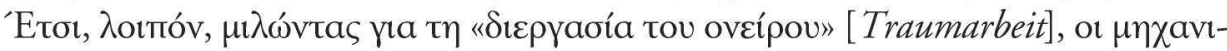

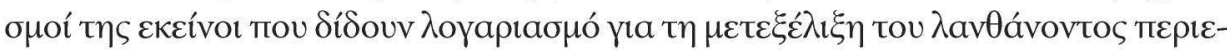

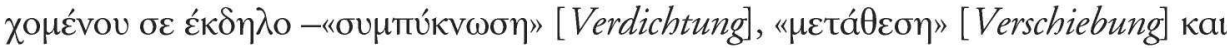

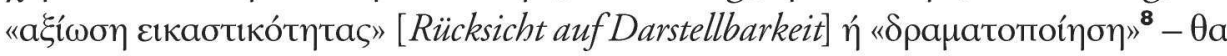

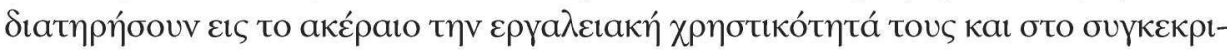

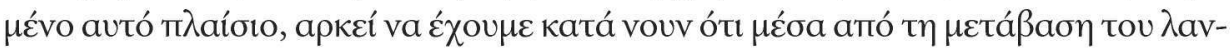

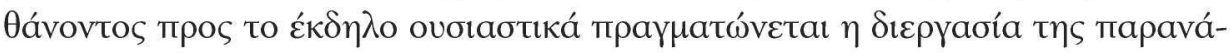




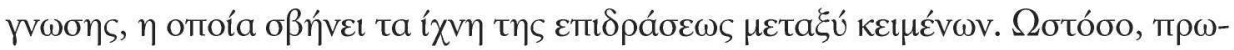

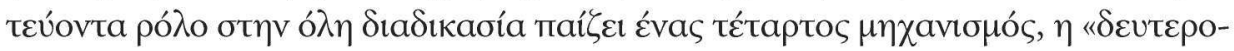

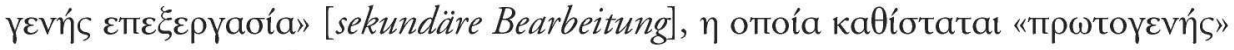

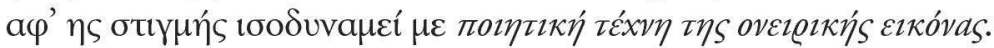

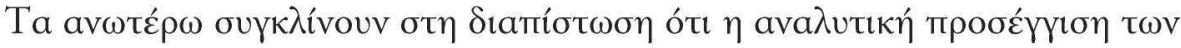

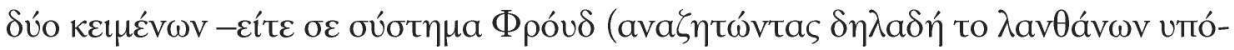

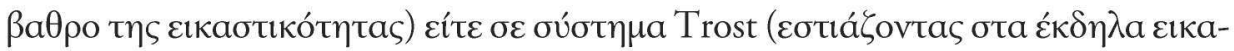

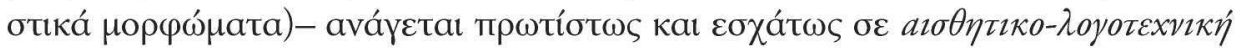

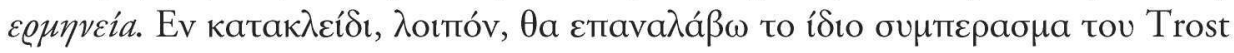

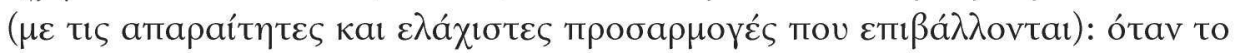

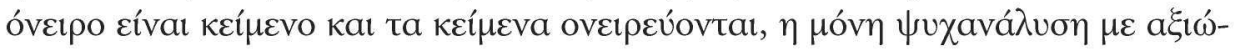

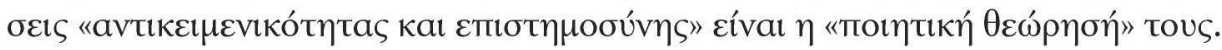

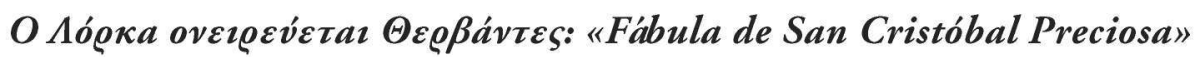

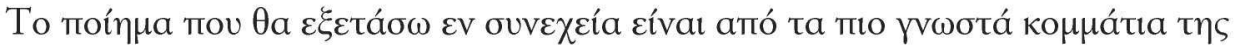

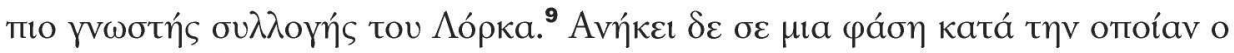

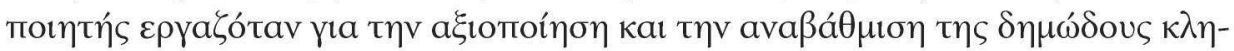

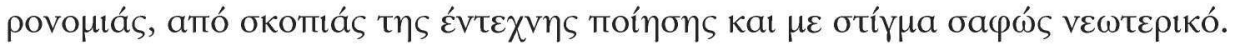

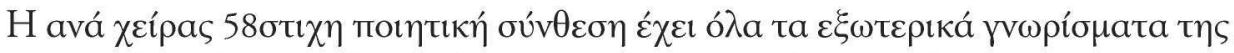

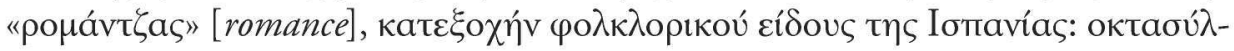

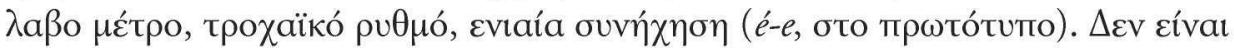

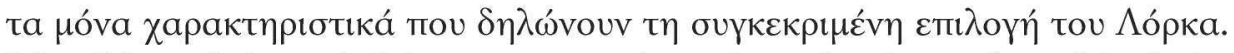

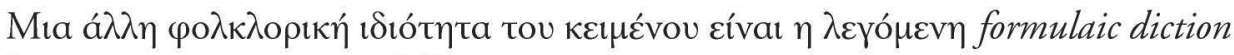

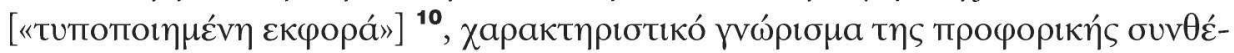

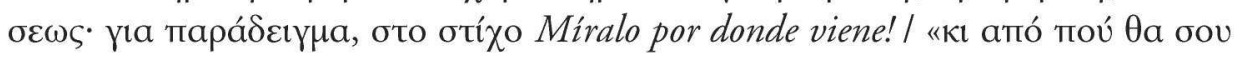

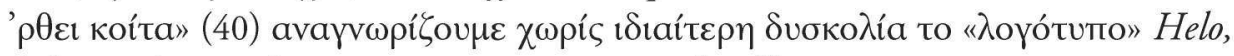

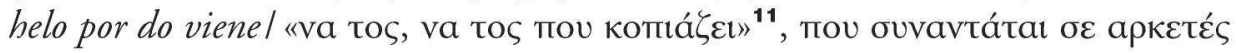

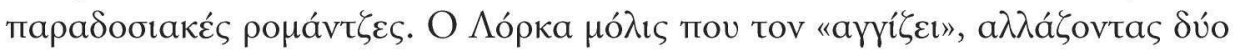

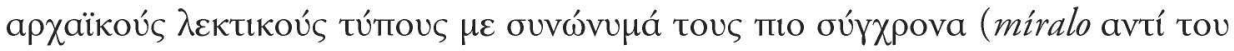

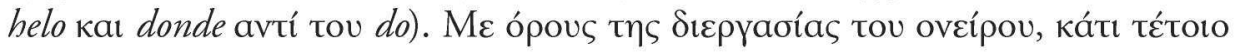

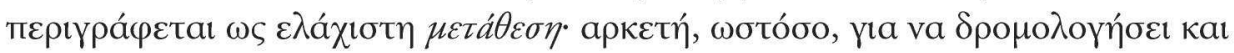

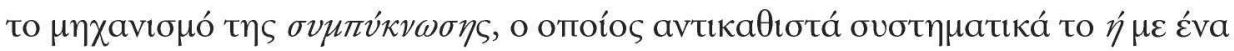

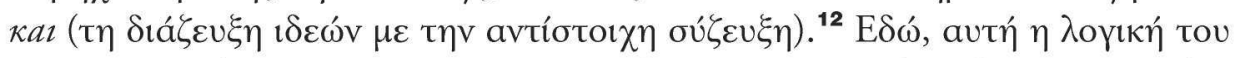

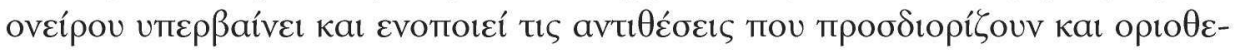

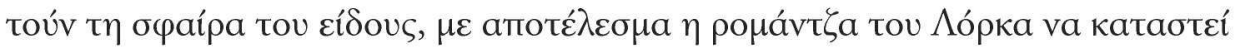

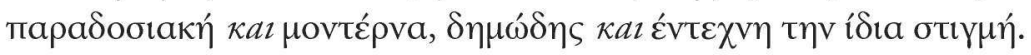




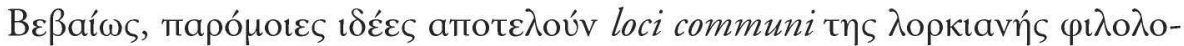

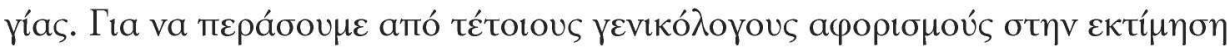

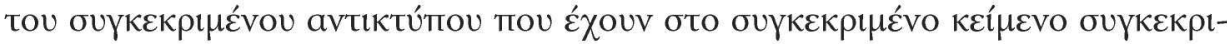

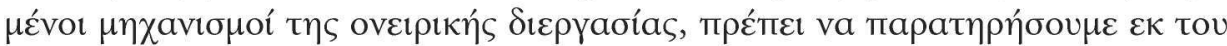

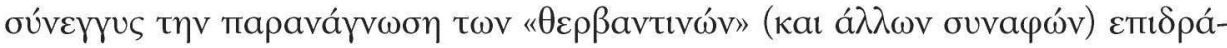

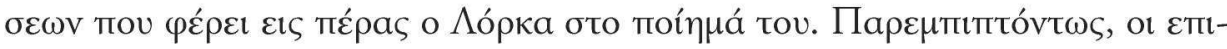

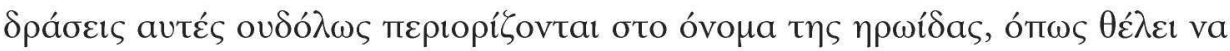

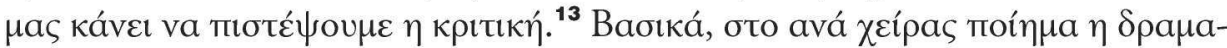

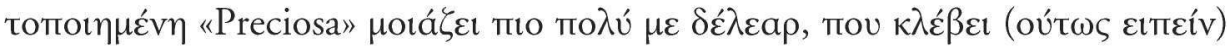

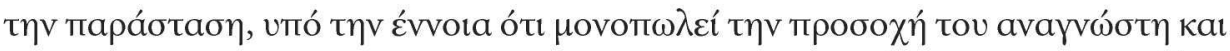

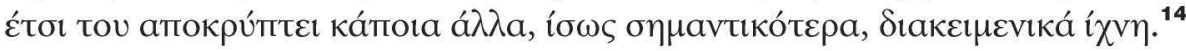

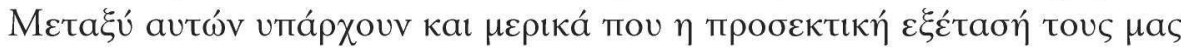

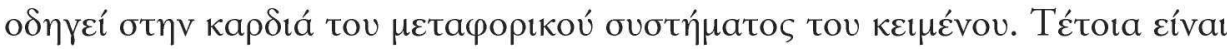

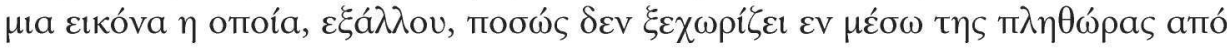

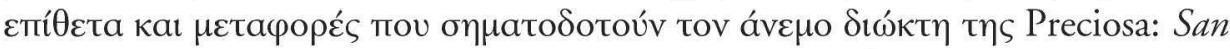

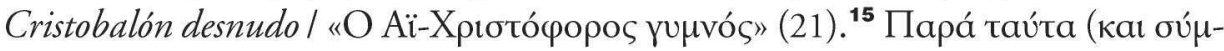

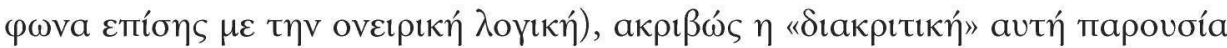

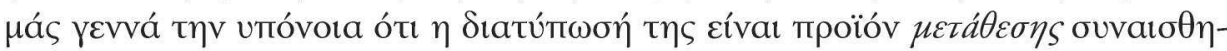

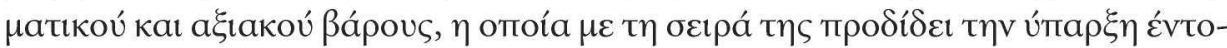

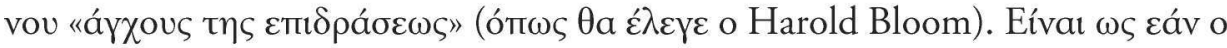

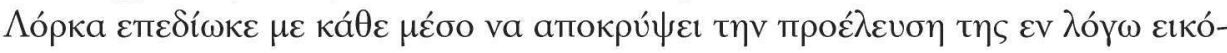

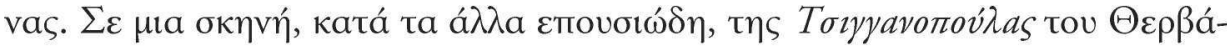

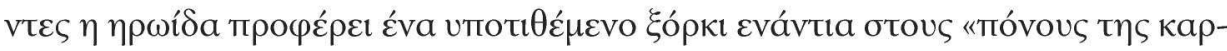

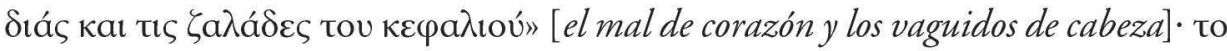

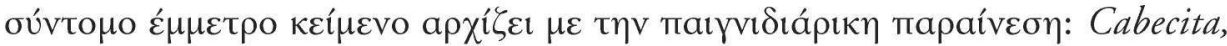

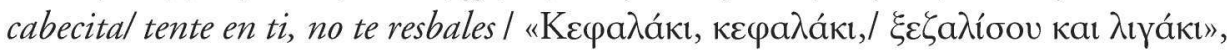

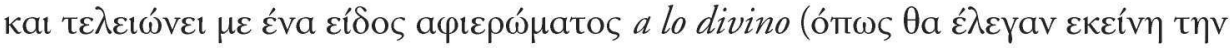

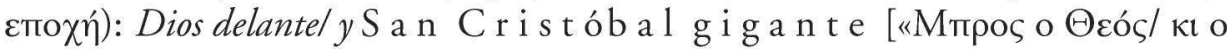
Aï-Хрıбтó

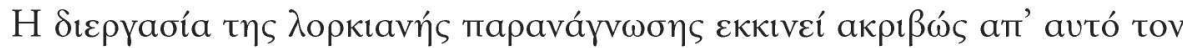
"Aï-Xрtбтó

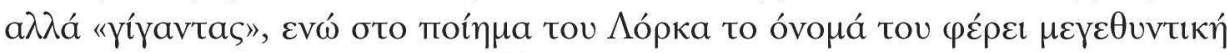

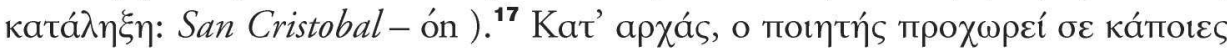

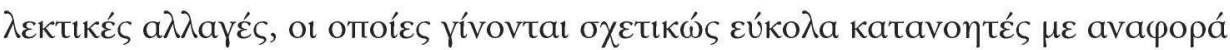

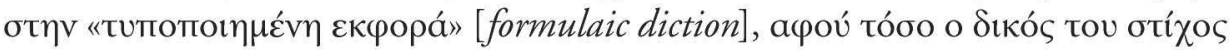

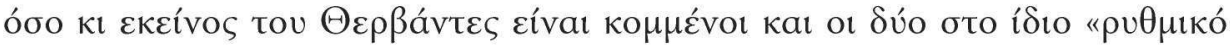

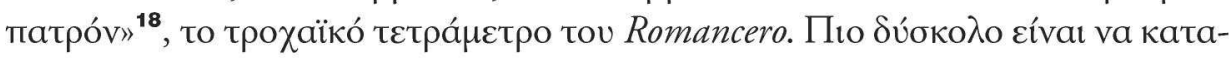




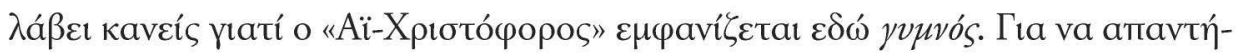

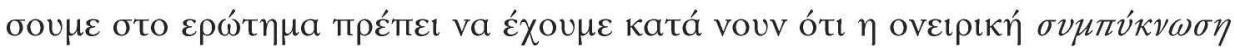

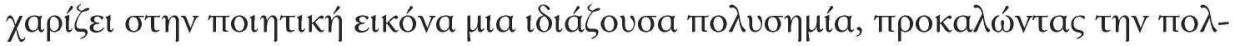

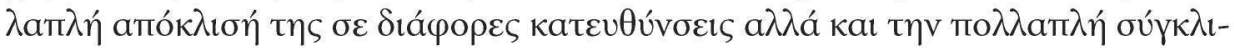

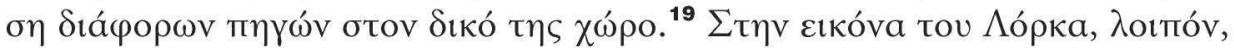

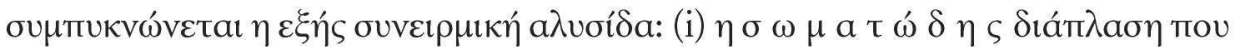

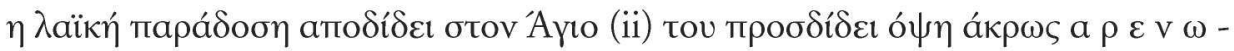

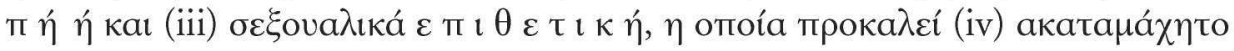

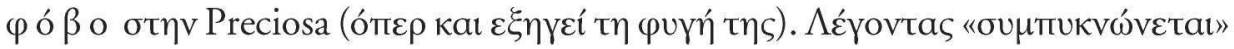

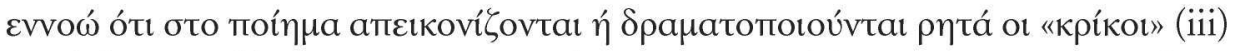

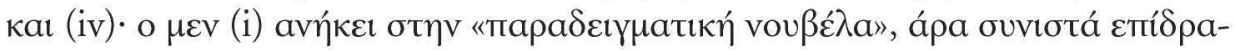

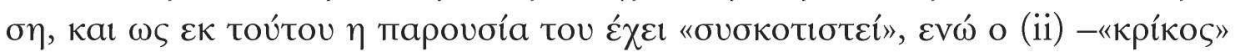

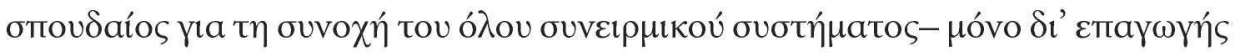

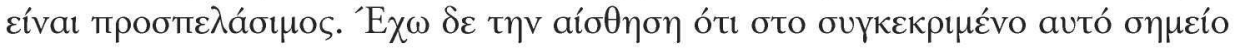

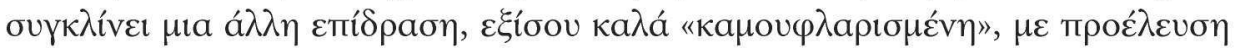

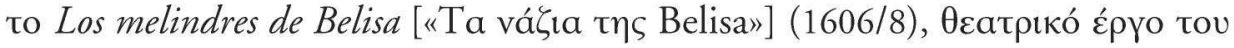

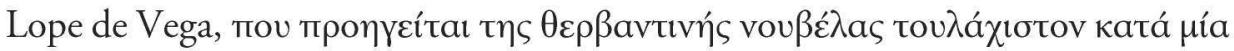

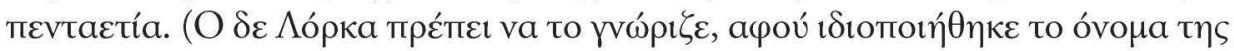

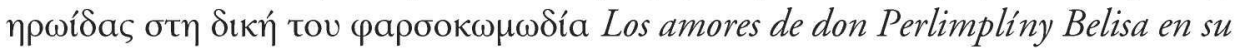

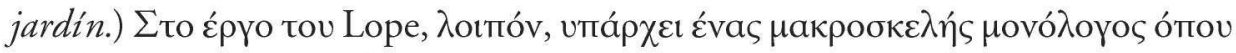

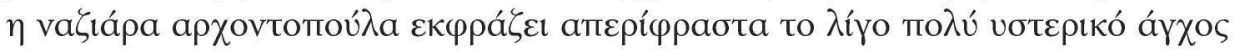

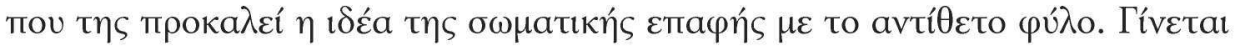
$\mu$ ád

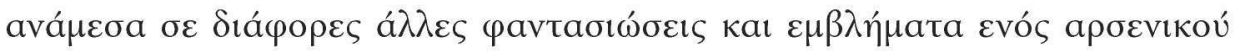

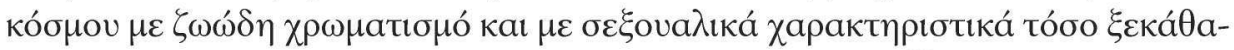

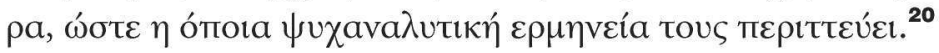

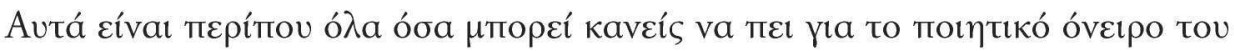

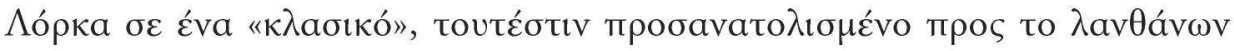

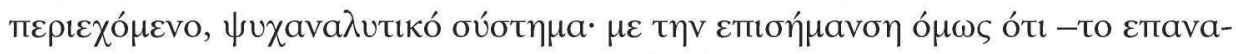

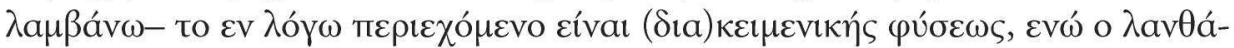

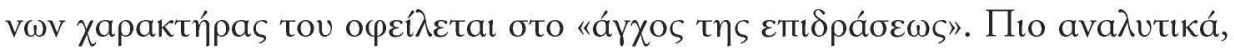

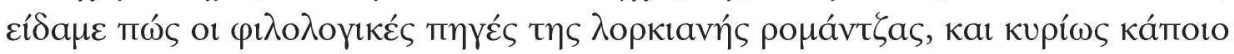

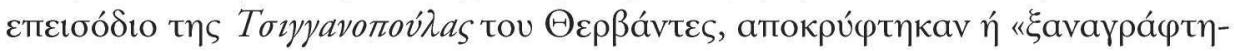

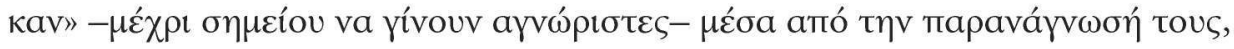

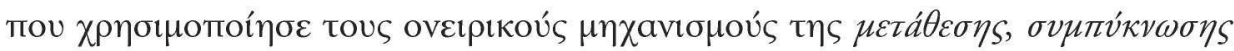




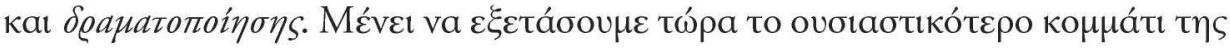

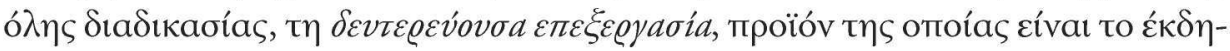

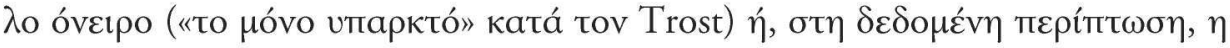

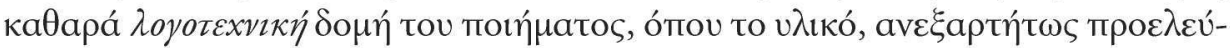

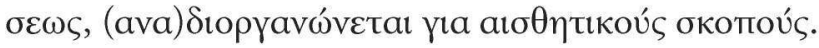

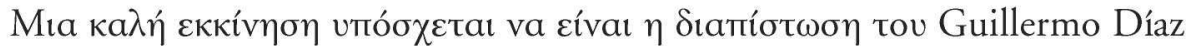

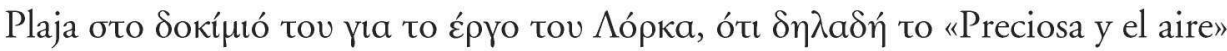

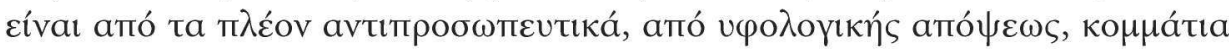

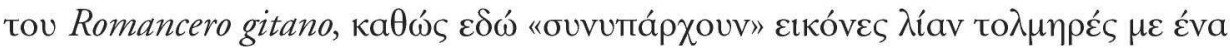

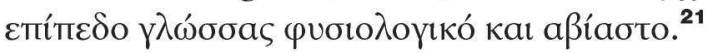

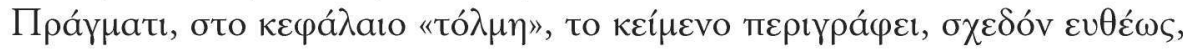

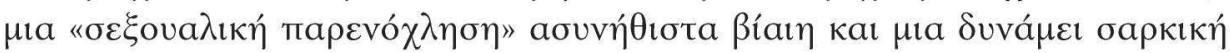

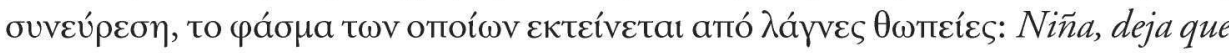
levantel tu vestido para verte./ Abre en mis dedos antiguos/ la rosa azul de tu vientre

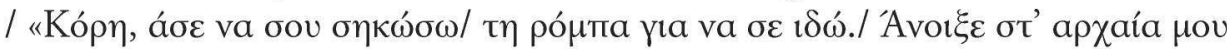

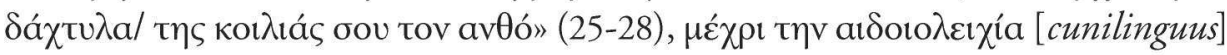

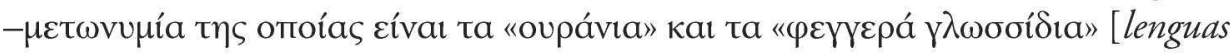

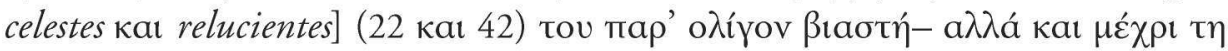

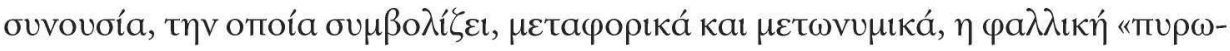

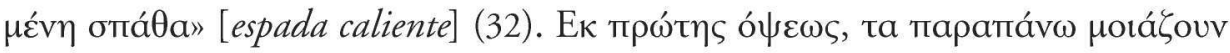

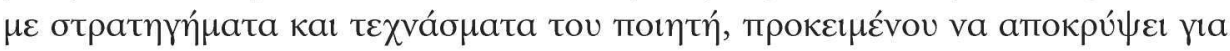

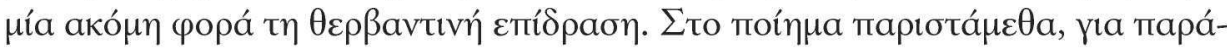

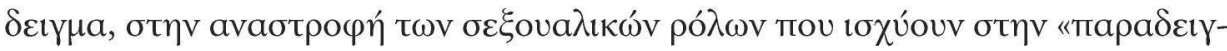

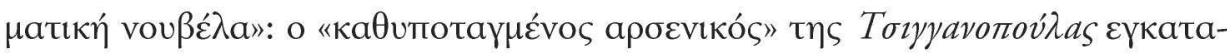

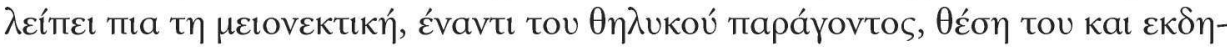

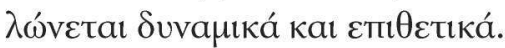

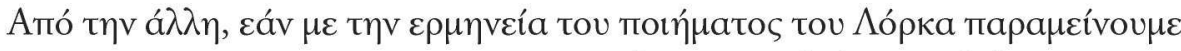

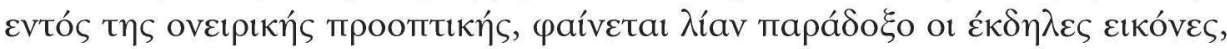

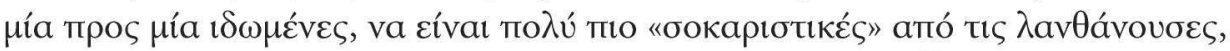

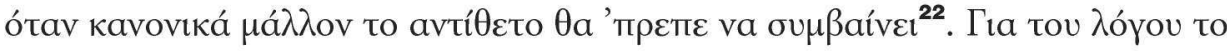

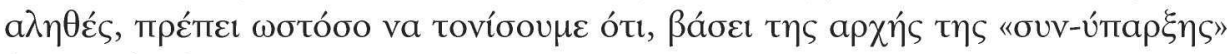
(Díaz Plaja), $\delta \eta \lambda a \delta \dot{~ т \eta ~}$

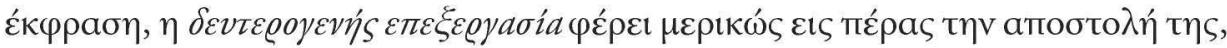

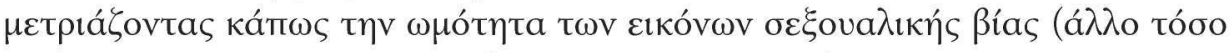

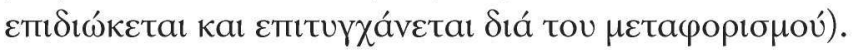

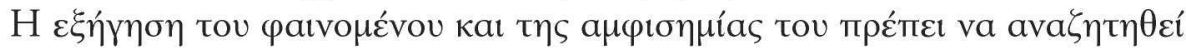

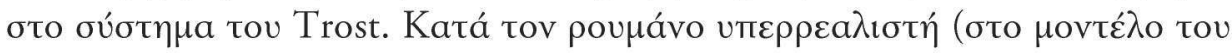




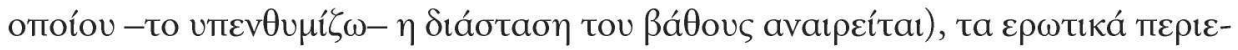

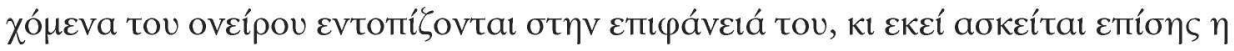

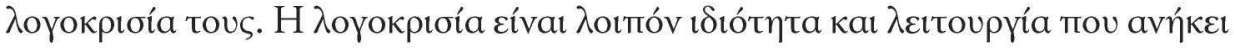

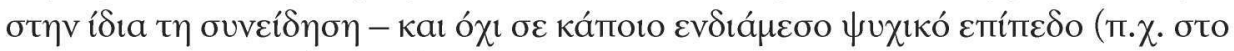

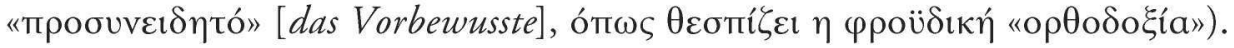

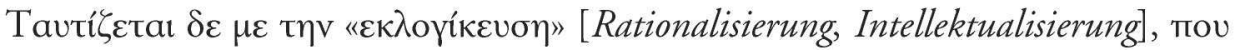

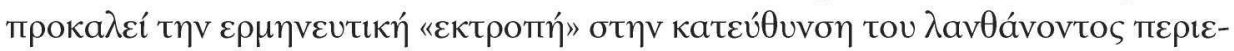

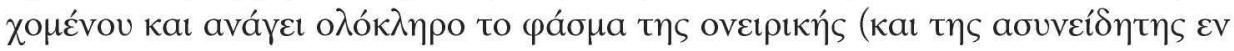

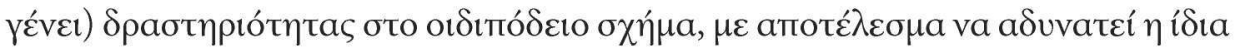

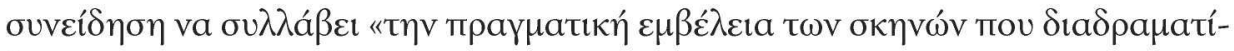

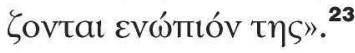

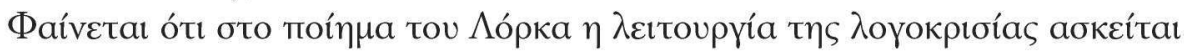

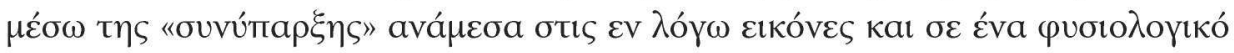

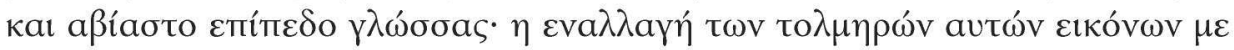

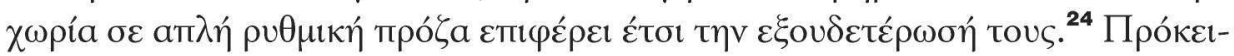

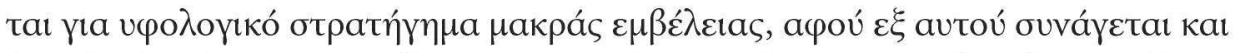

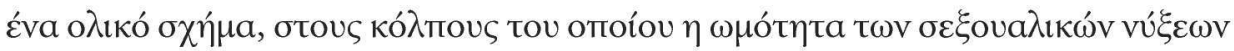

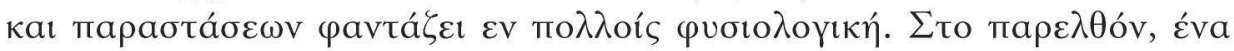

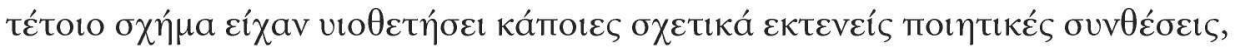

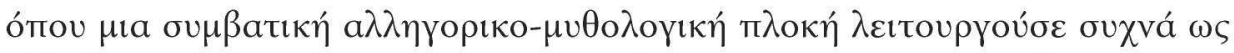

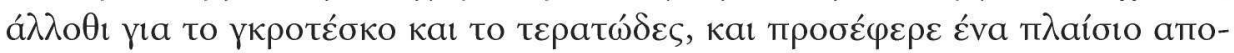

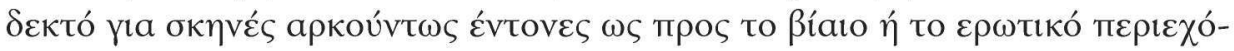

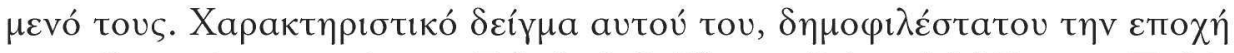

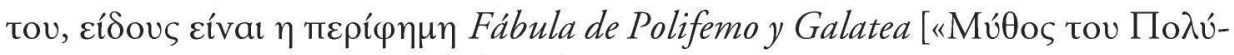

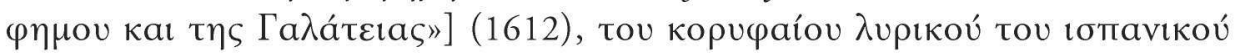
нтаро́к, Luis de Góngora y Argote (1561-1627).

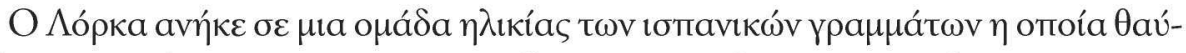

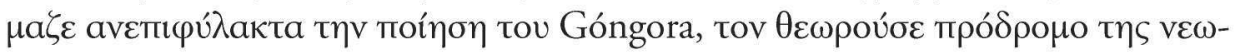

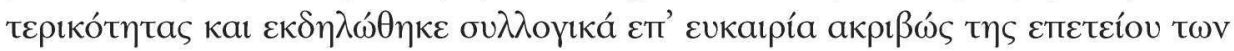

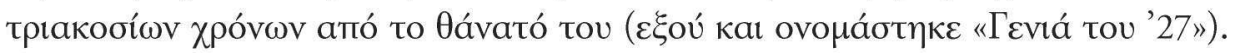

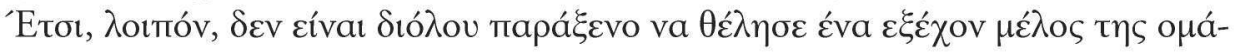

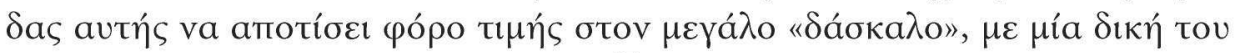

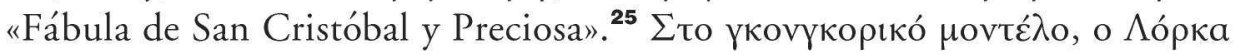

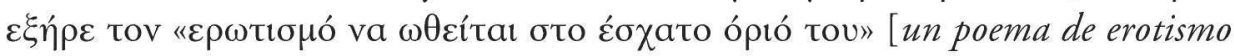

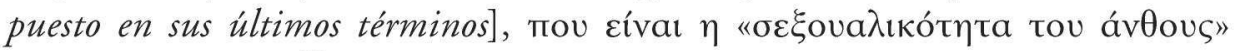

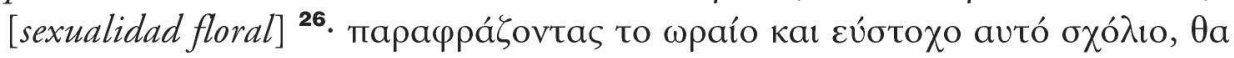

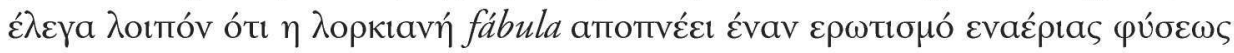




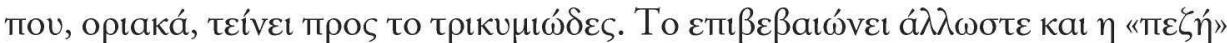

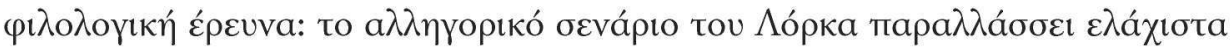

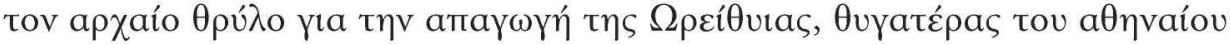

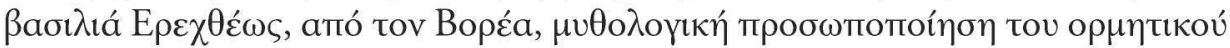

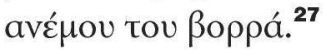

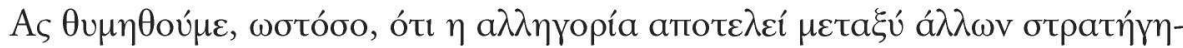

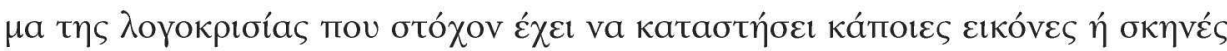

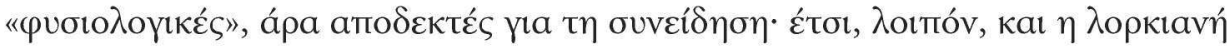

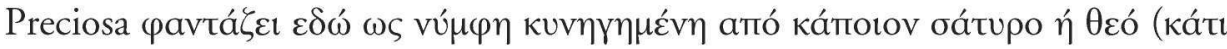

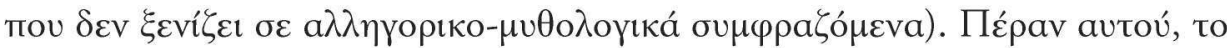

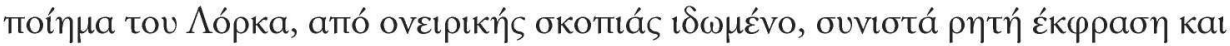

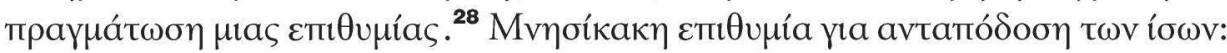

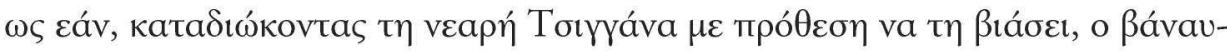

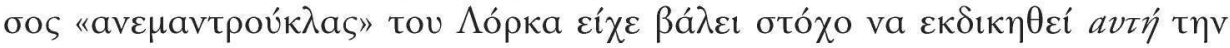

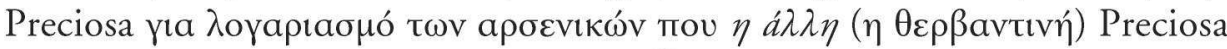

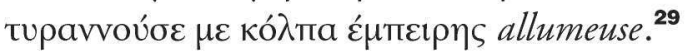

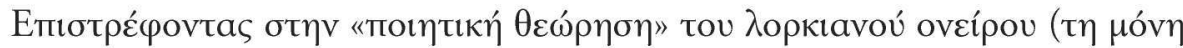

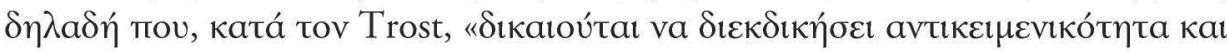

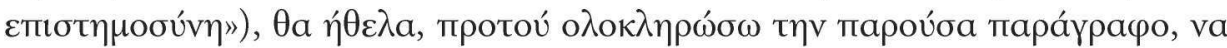

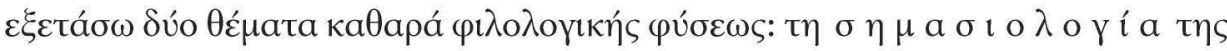

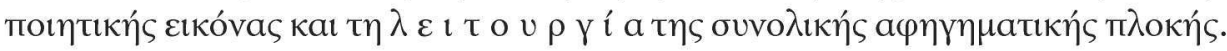

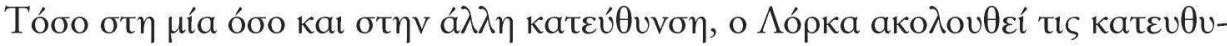

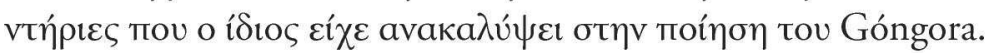

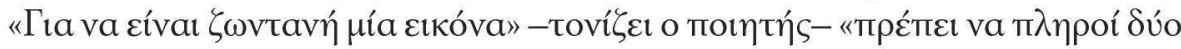

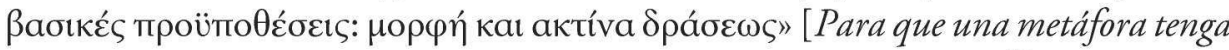
vida necesita dos condiciones fundamentales: forma y radio de acción $].{ }^{30}$ Ava $\lambda$ úovtas

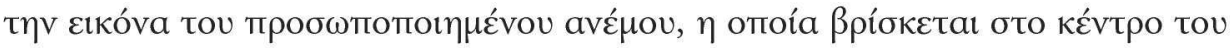

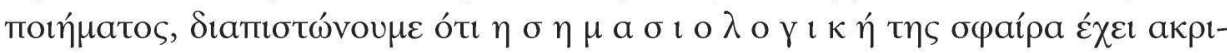

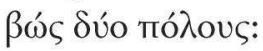

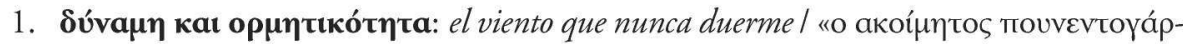

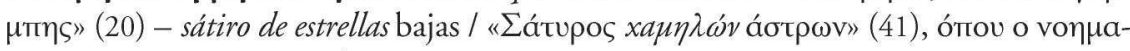

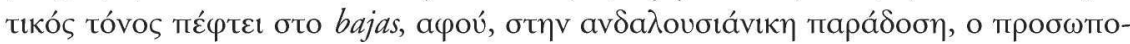

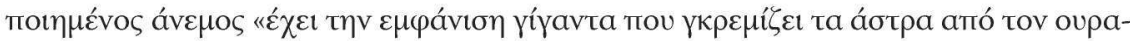

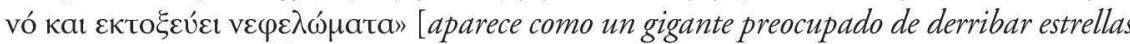

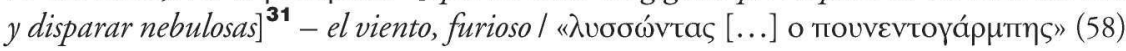

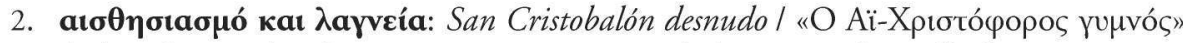

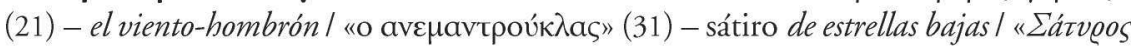




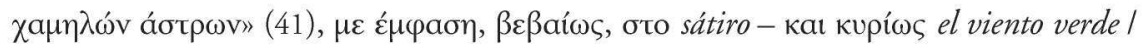

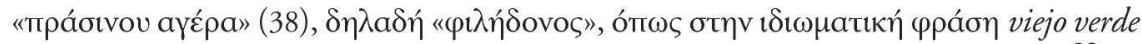

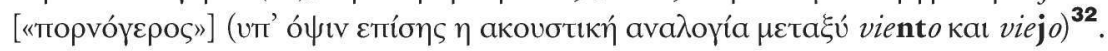

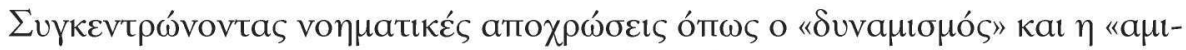

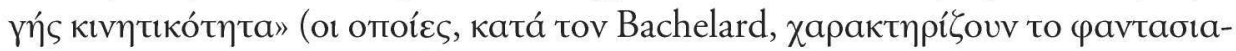

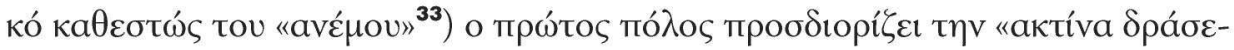

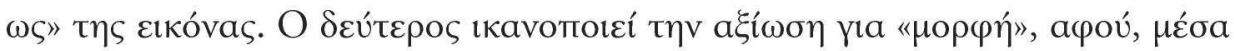

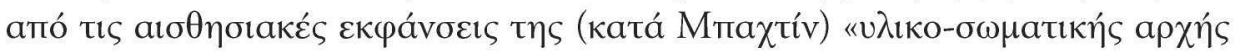

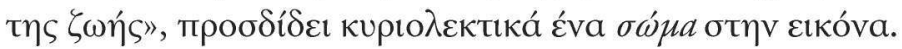

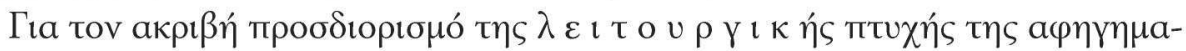

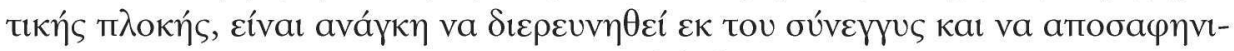

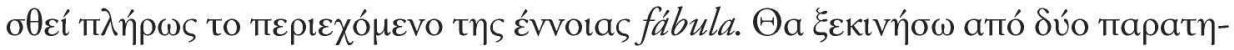

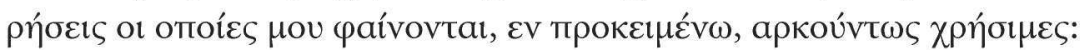

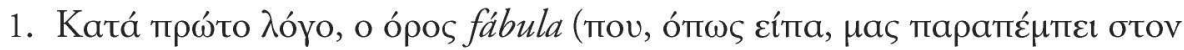

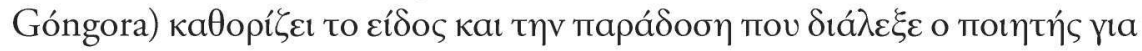

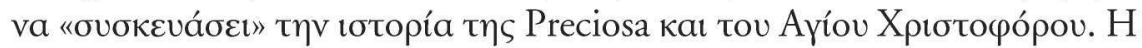

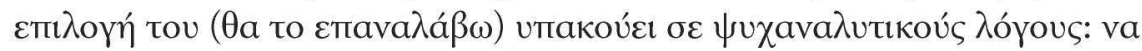

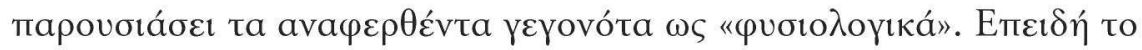

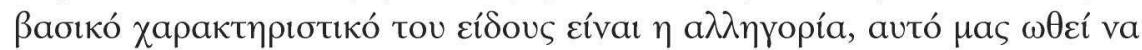

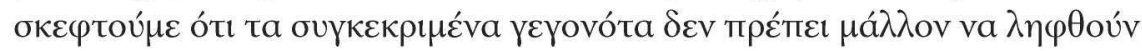

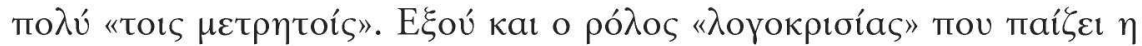

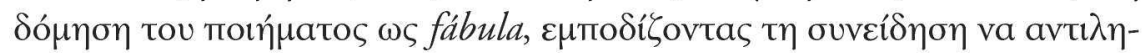

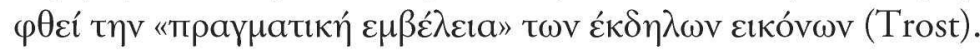

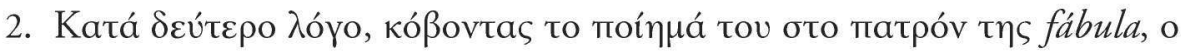

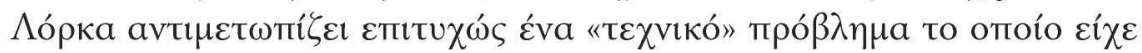

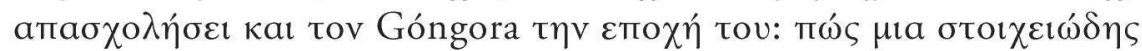

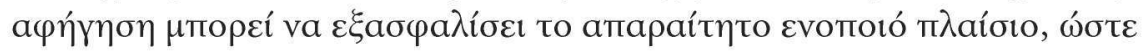

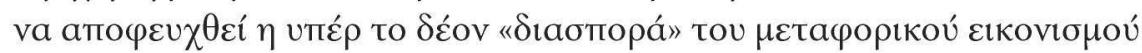

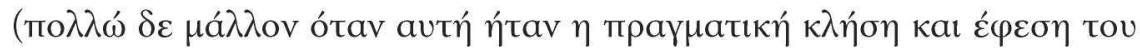

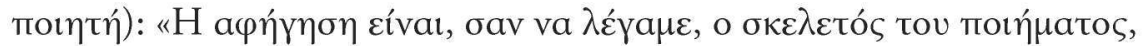

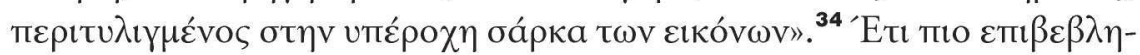

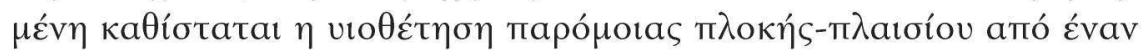

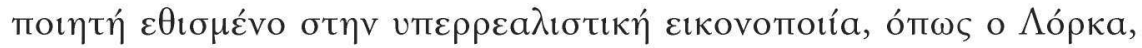

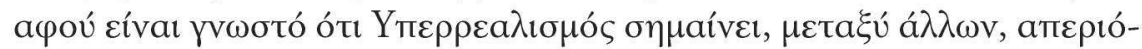

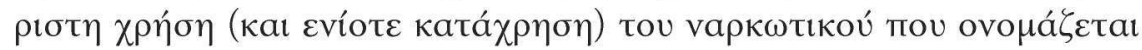
нєтарора́. 


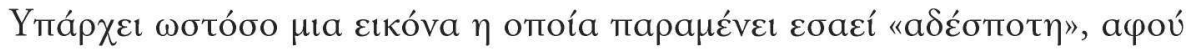

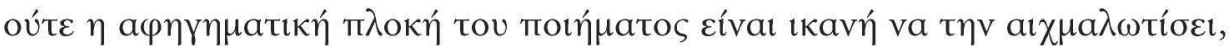

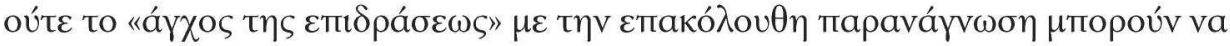

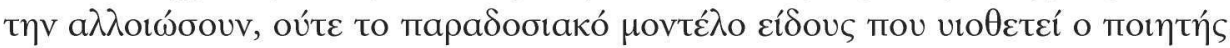

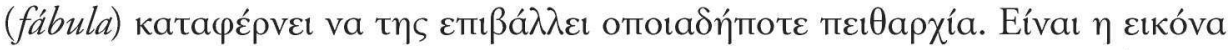

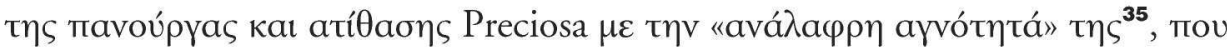

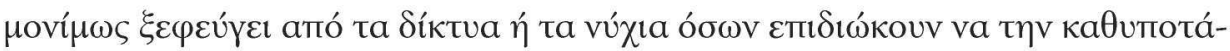

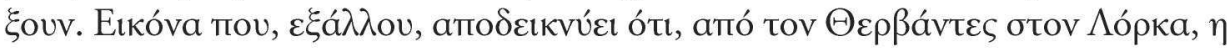

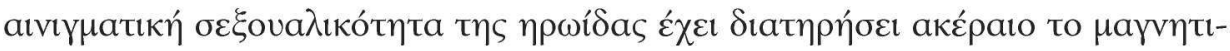

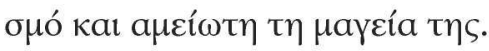

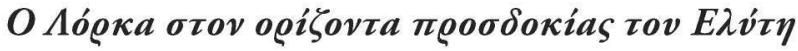

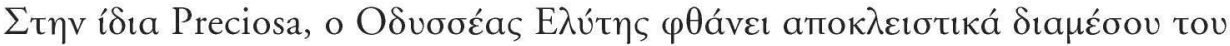

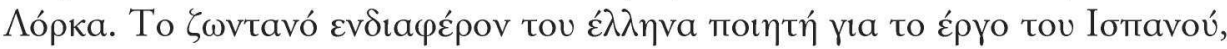

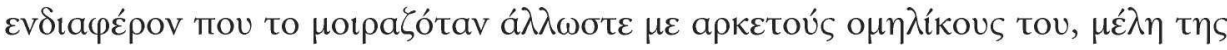

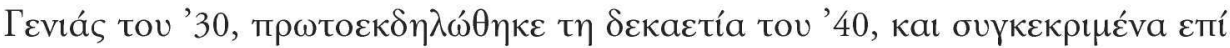

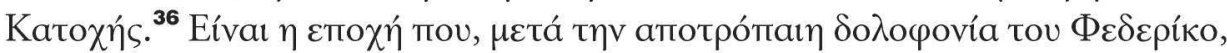

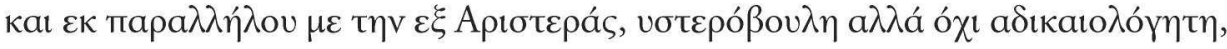

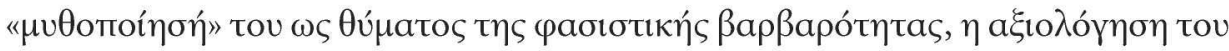

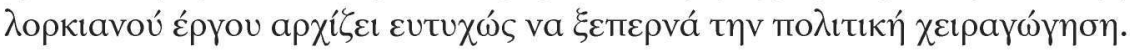

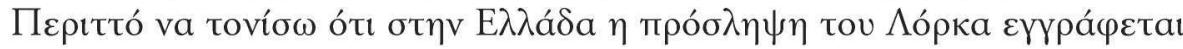

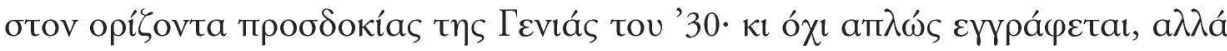

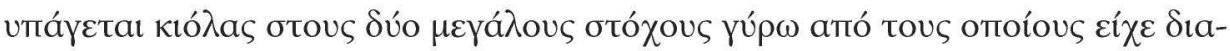

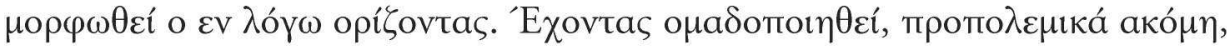

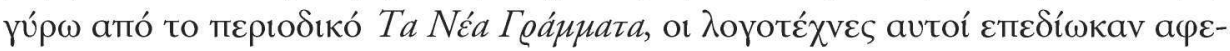

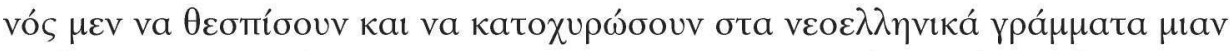

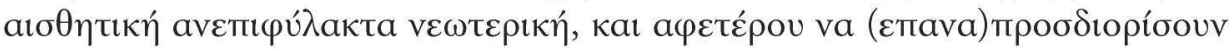

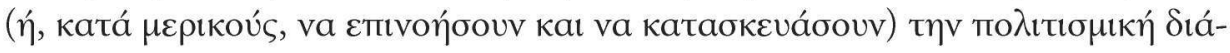

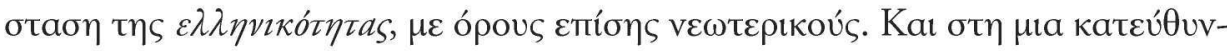

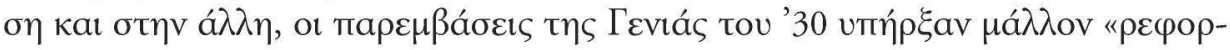

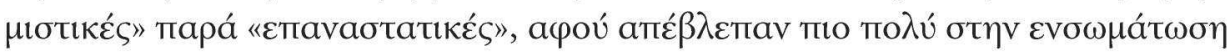

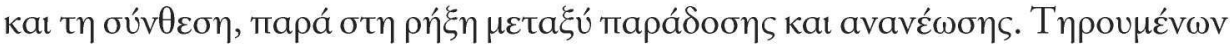

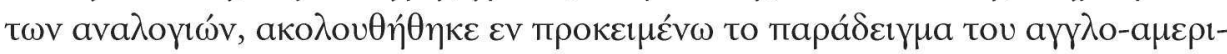

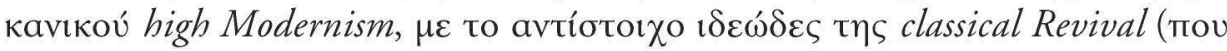

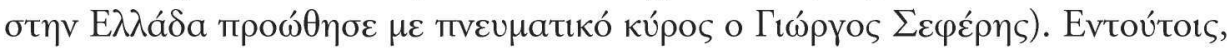

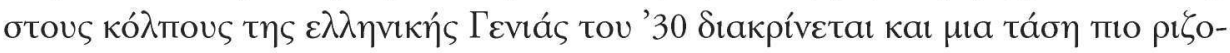




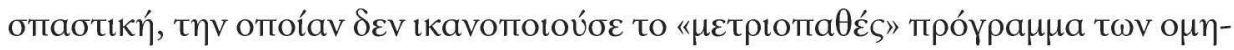

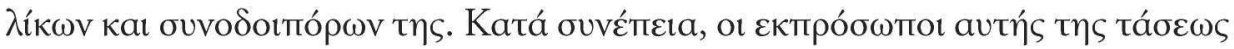

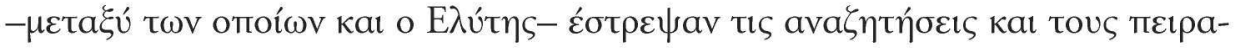

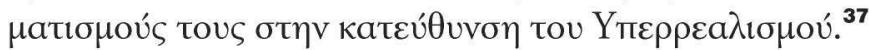

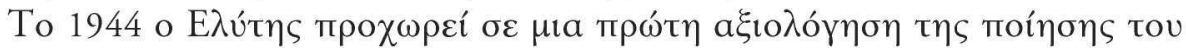

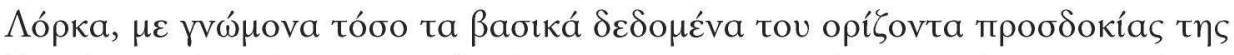

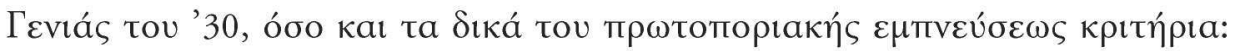

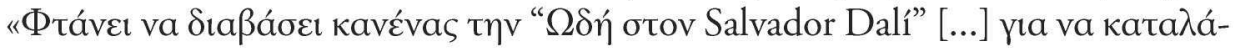

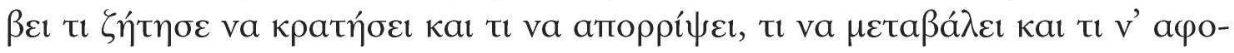

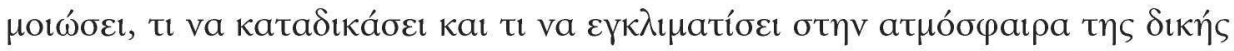

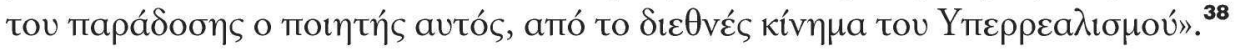

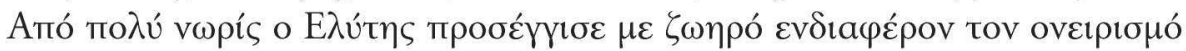

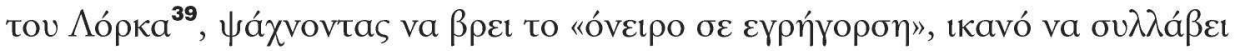

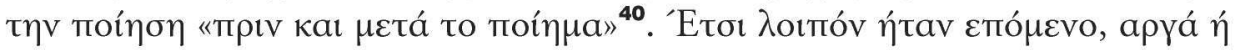

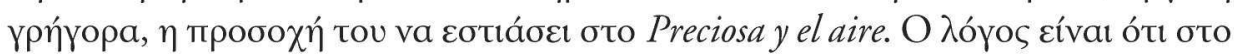

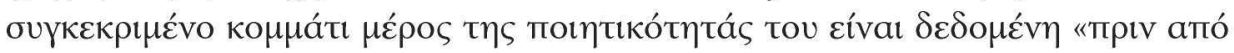

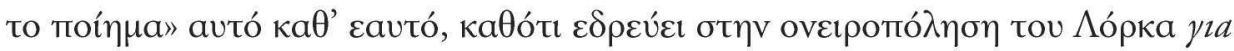

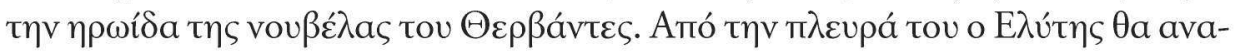

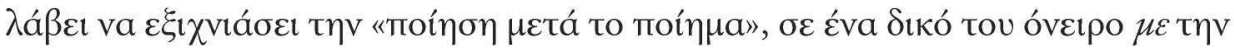
$\eta \rho \omega i ́ \delta a$ tov oveípou tov $\Lambda$ ópкa.

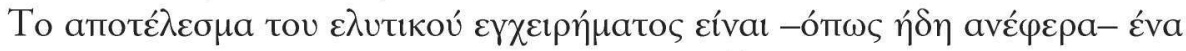

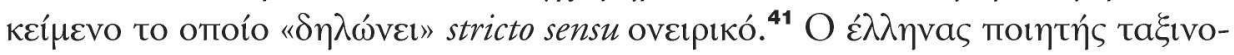

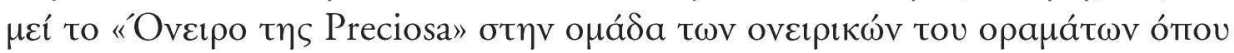

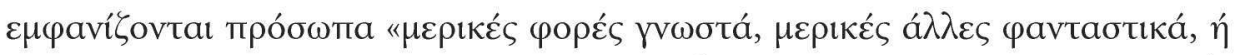

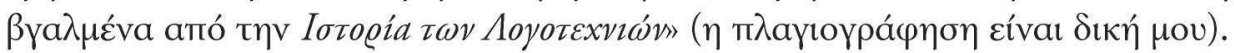

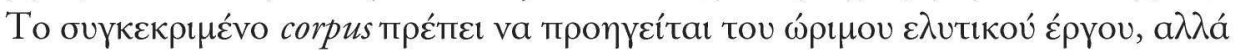

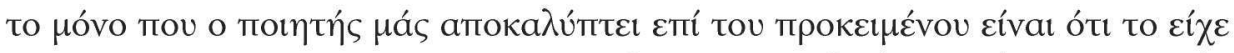

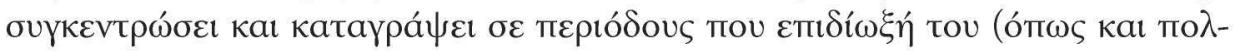

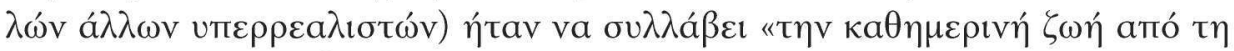

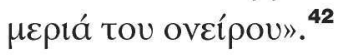

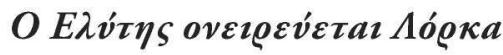

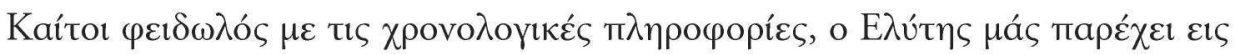

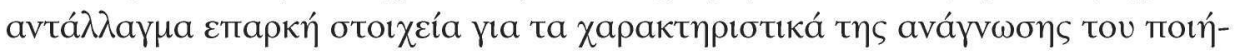

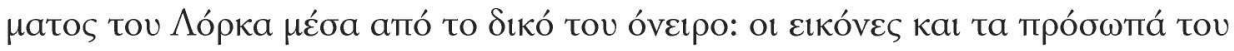

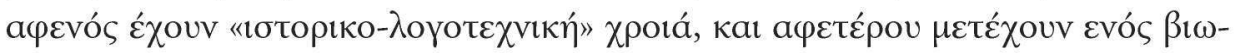




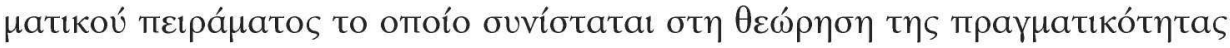

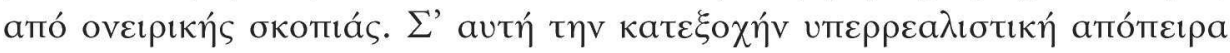

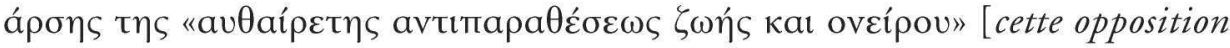

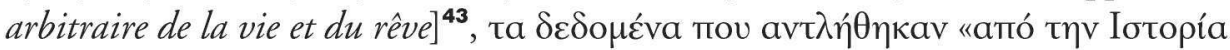

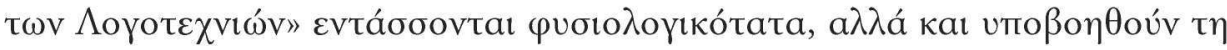

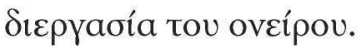

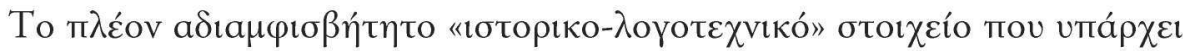

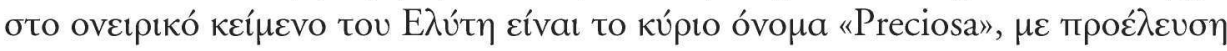

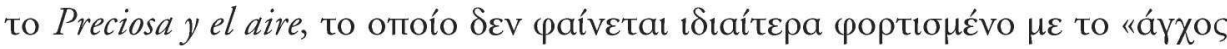

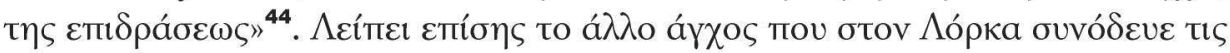

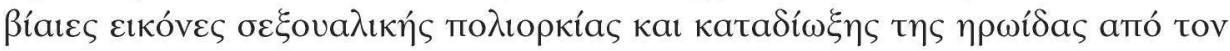

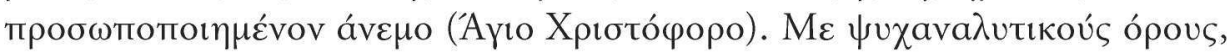

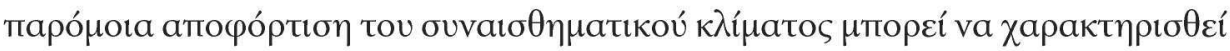

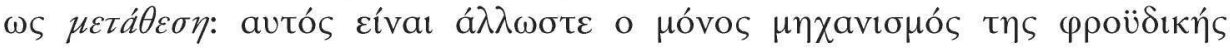

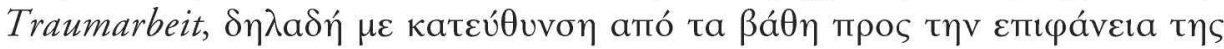

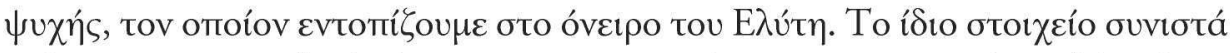

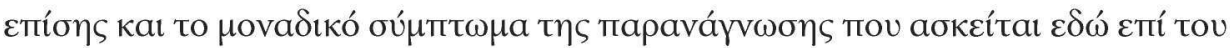

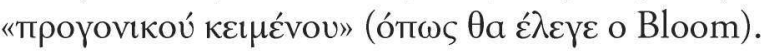

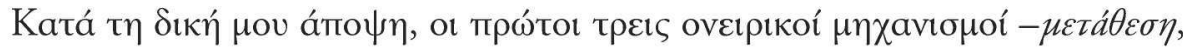

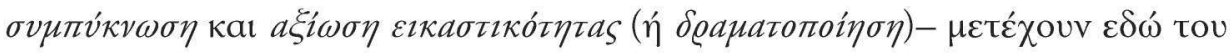

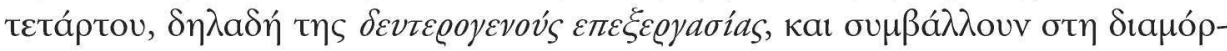

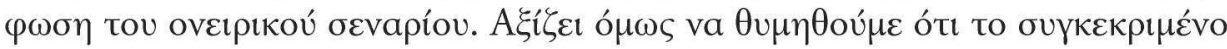

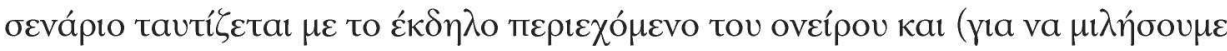

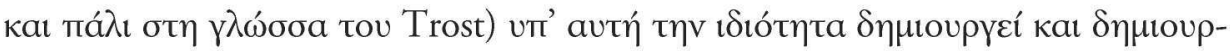

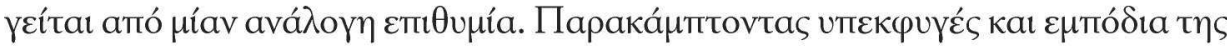

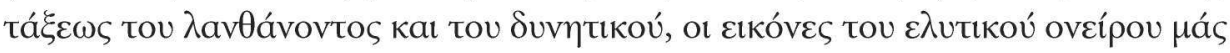

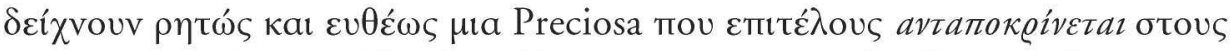

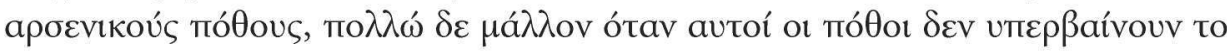

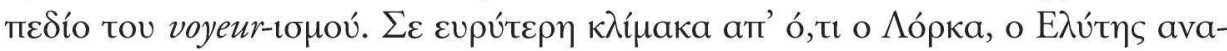

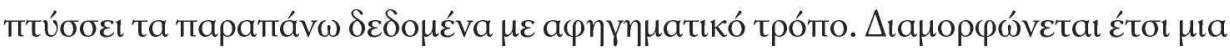

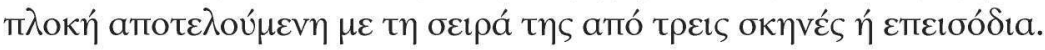

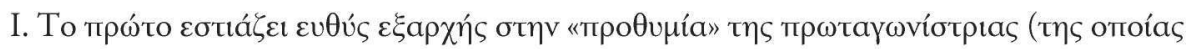

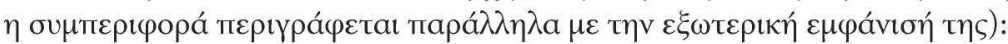

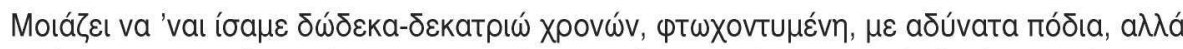
пр

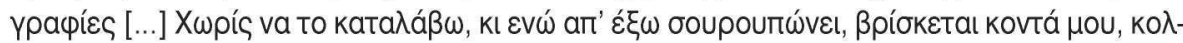

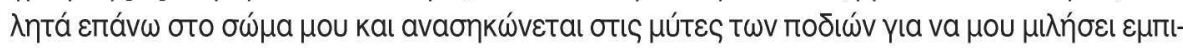




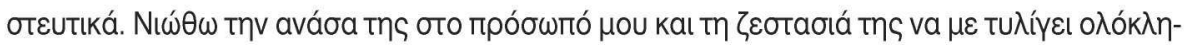

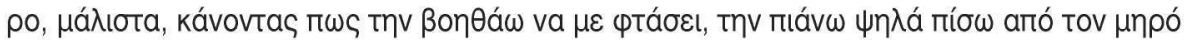

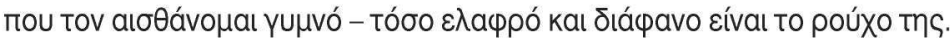

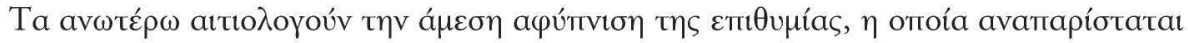

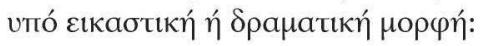

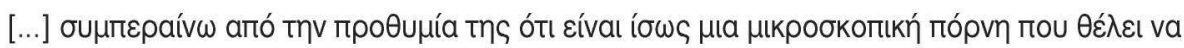

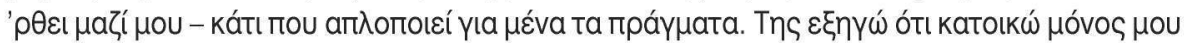

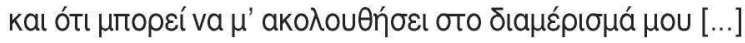

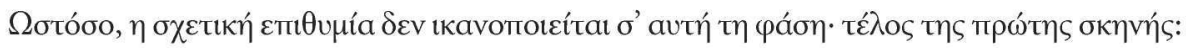

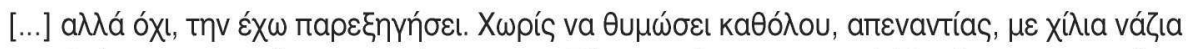

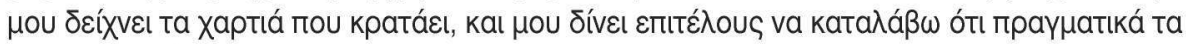

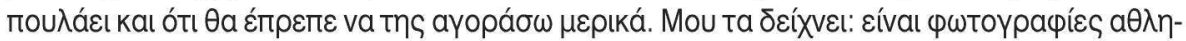

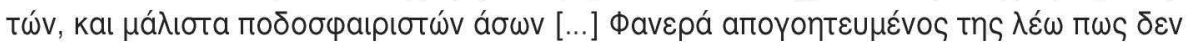

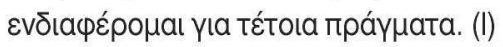

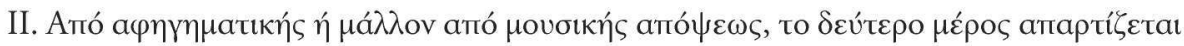

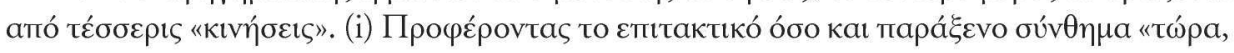

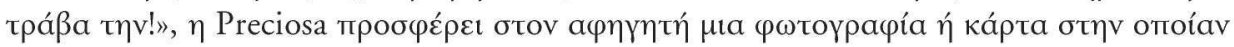

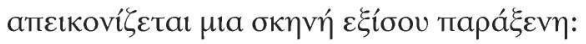

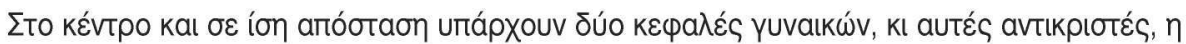

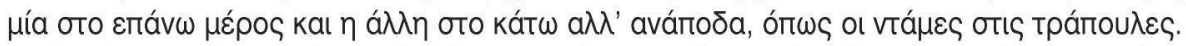

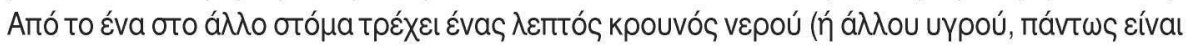

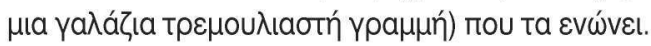

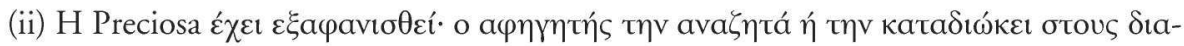

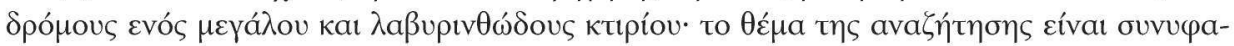

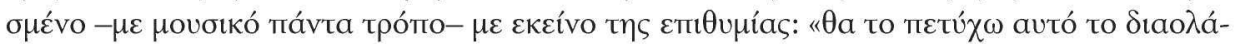

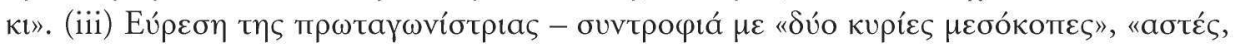

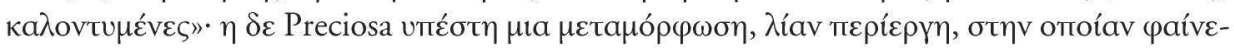

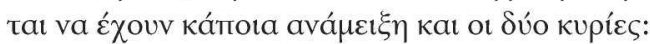

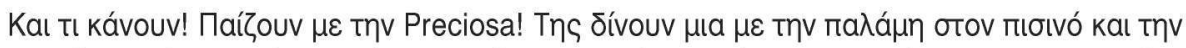

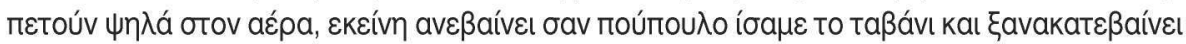

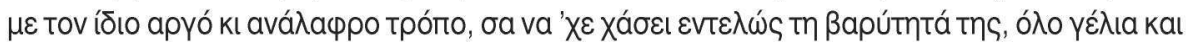

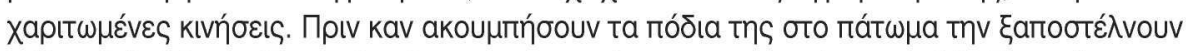

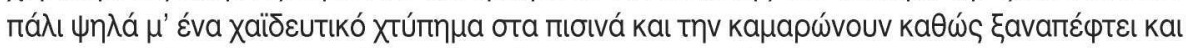

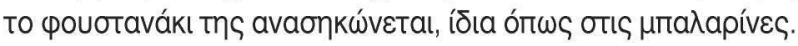

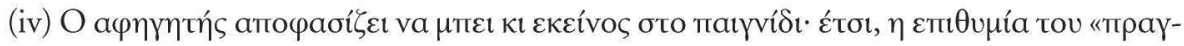

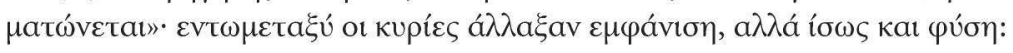

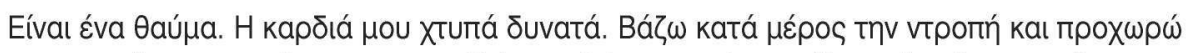

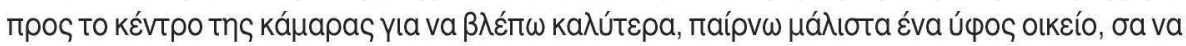

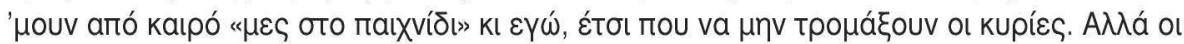




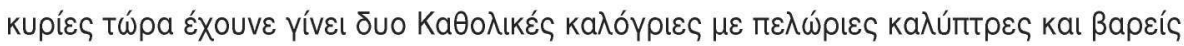

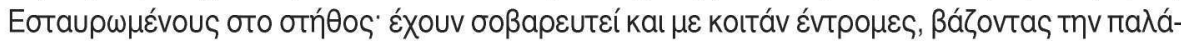

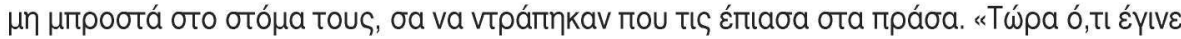

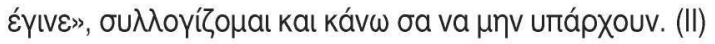

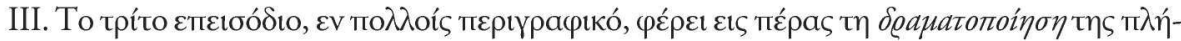

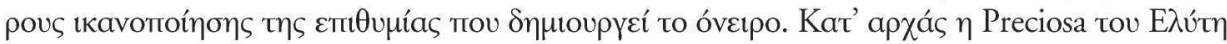

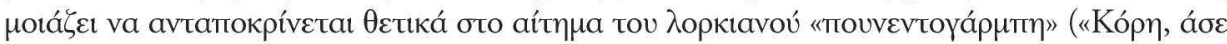

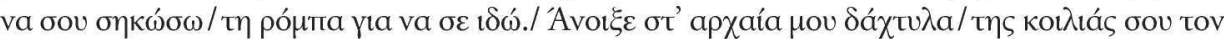

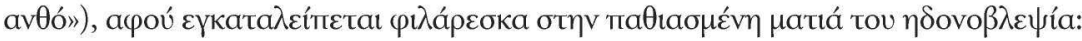

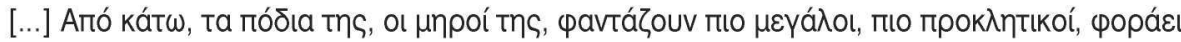

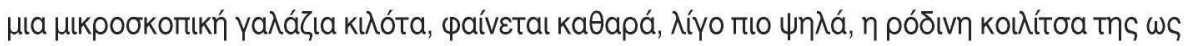

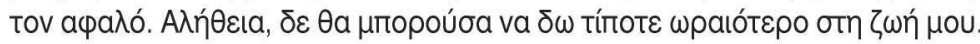

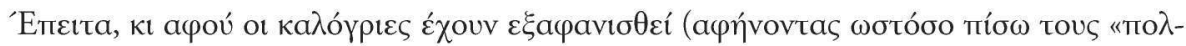

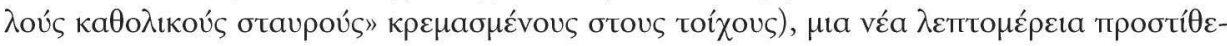

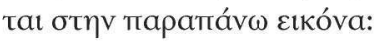

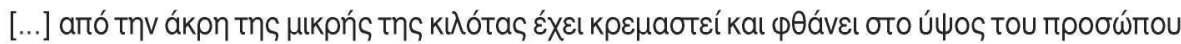

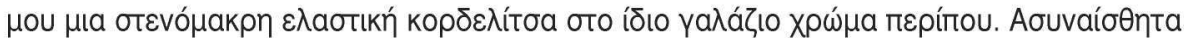

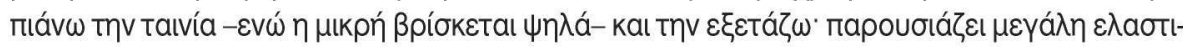

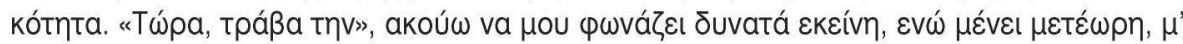

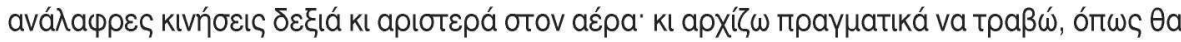

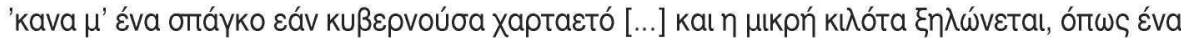

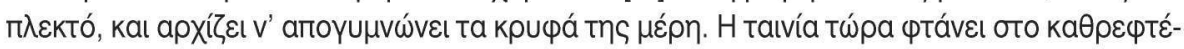

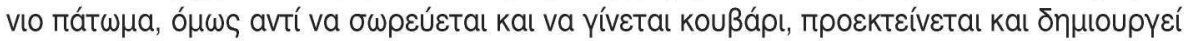

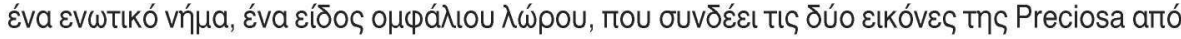

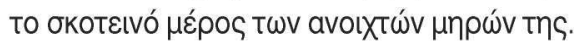

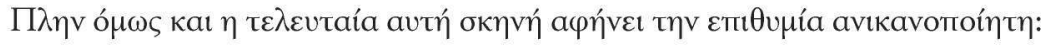

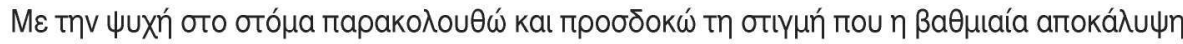

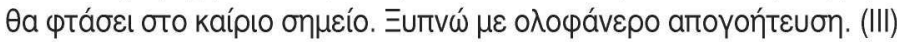

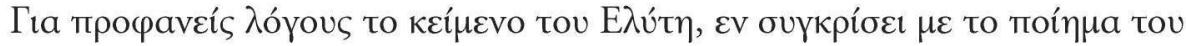

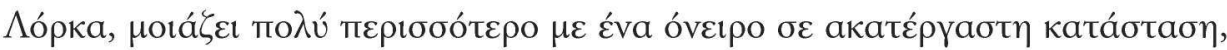

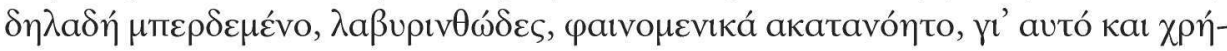

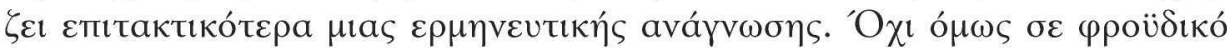

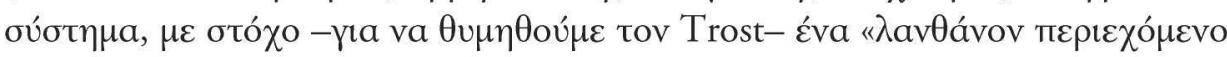

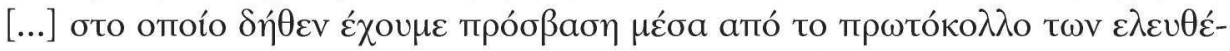

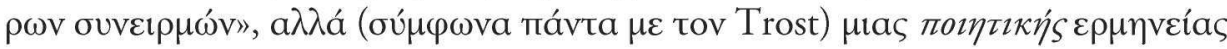

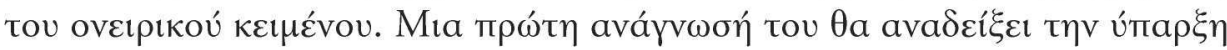

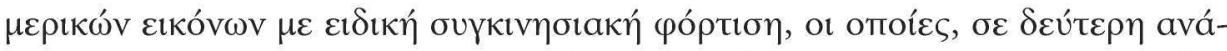

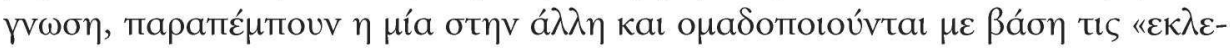




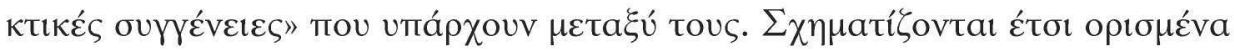

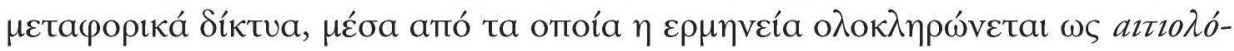

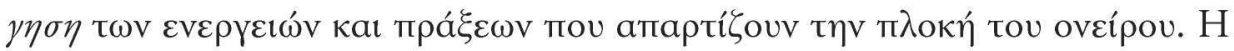

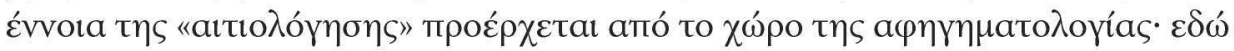

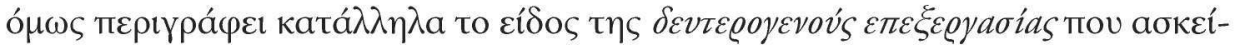

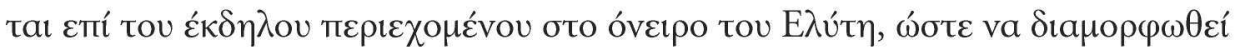

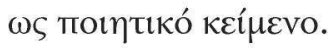

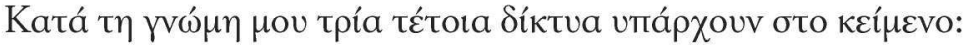

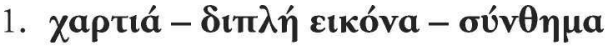

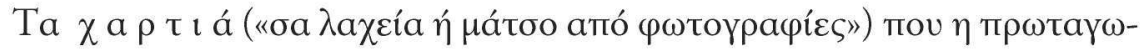

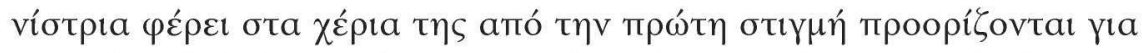

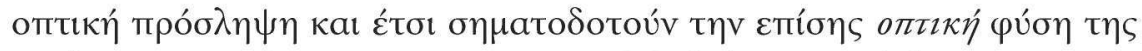

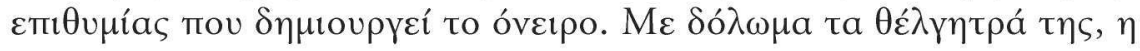

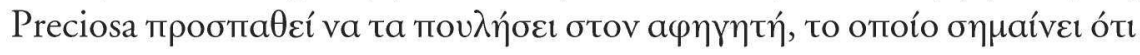

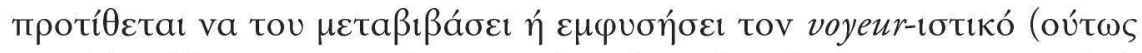

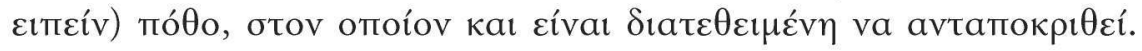

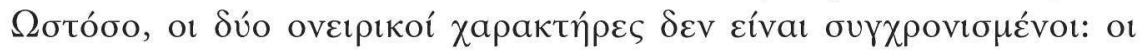

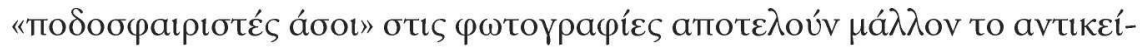

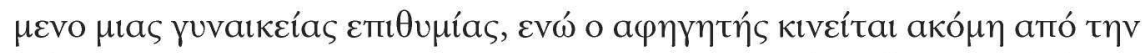

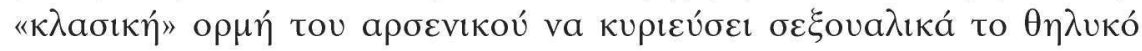

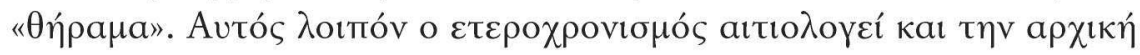

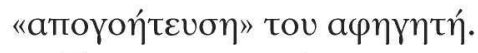

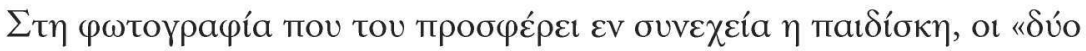

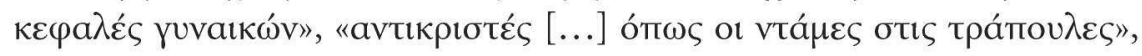

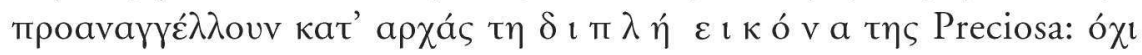

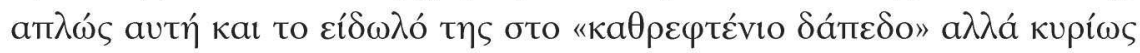

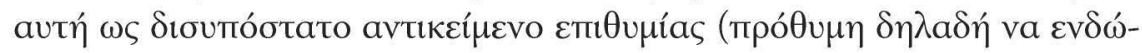

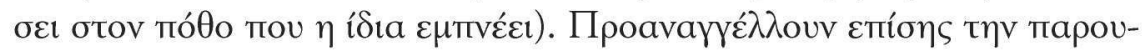

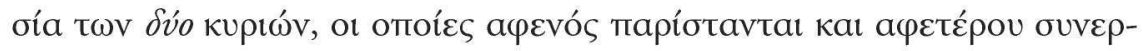

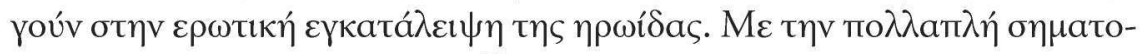

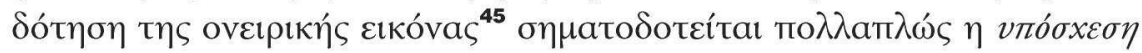

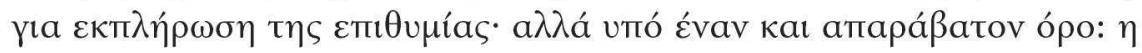

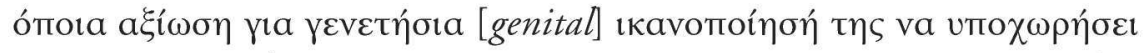

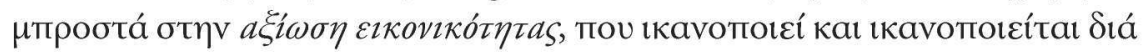

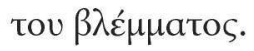




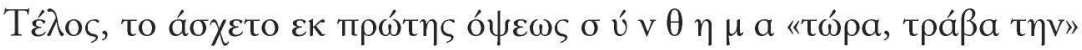

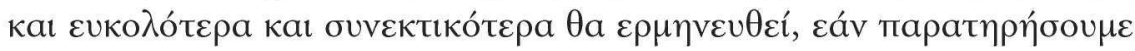

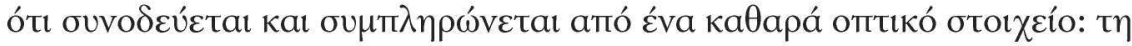

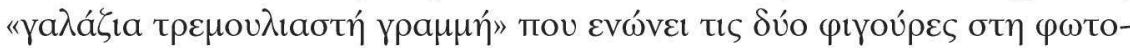

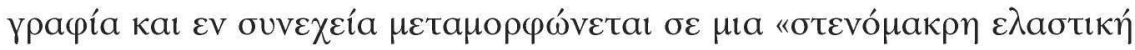

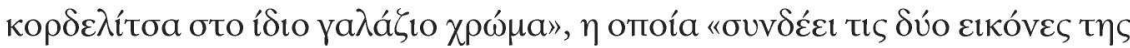

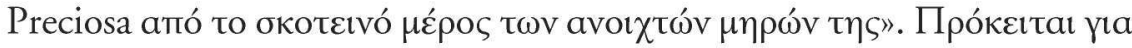

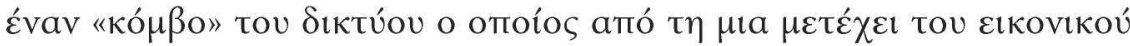

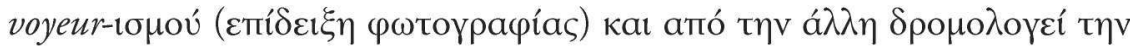

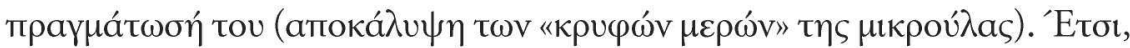

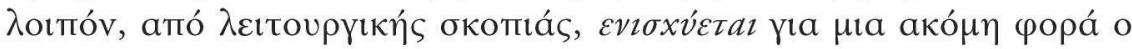

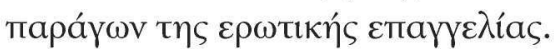

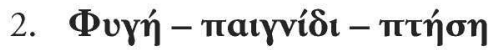

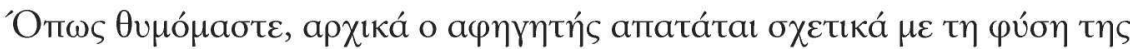

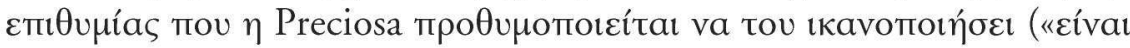

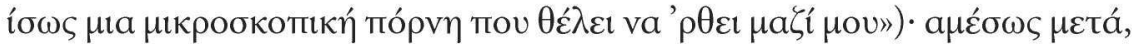

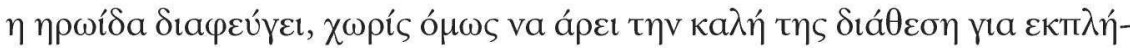


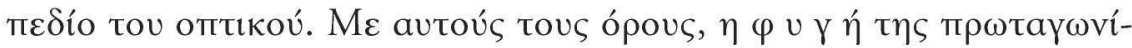

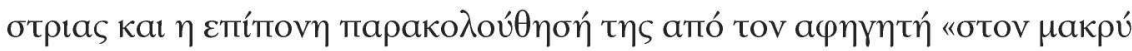

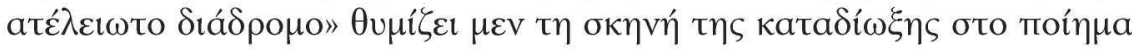

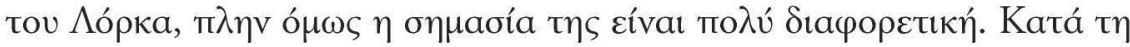

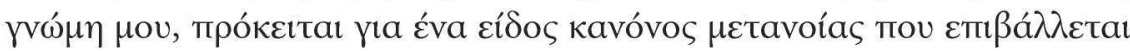

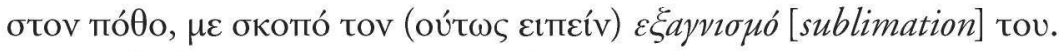

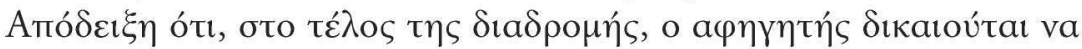

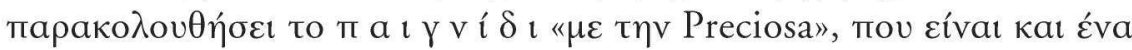

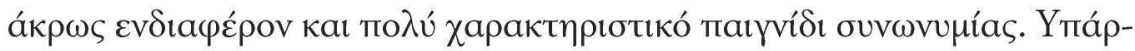

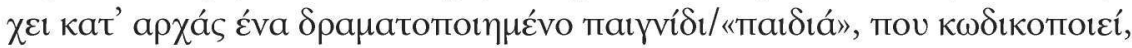

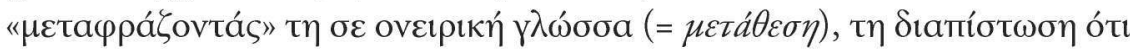

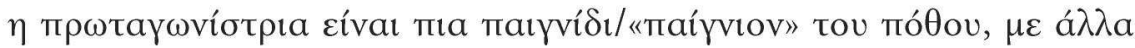

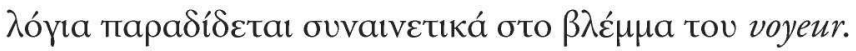

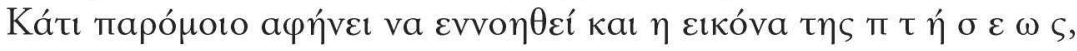

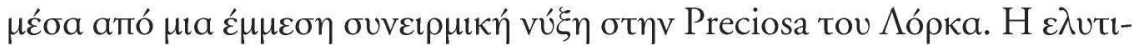

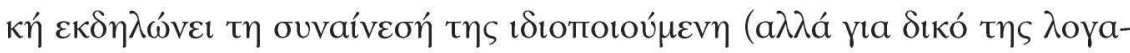

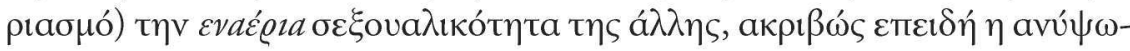




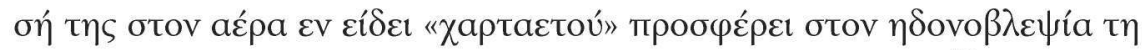

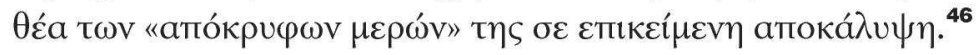

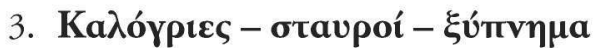

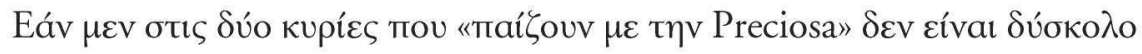

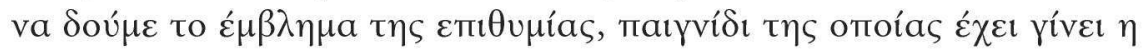

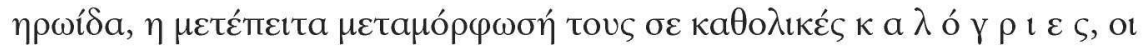

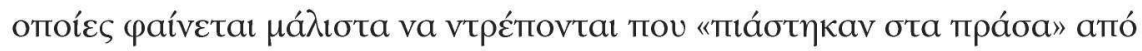

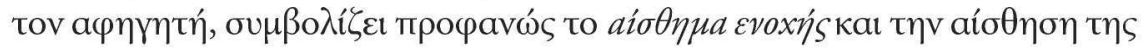

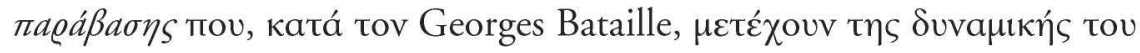

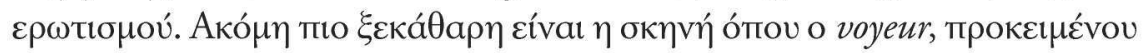

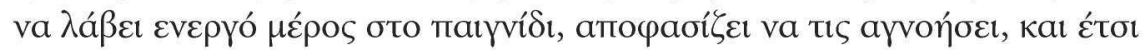

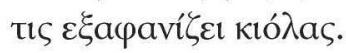

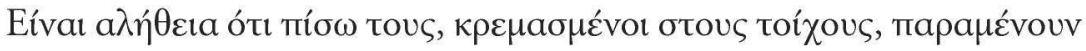

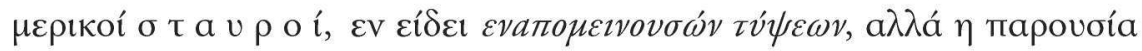

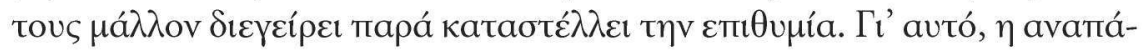

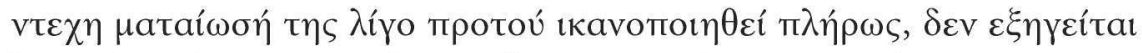

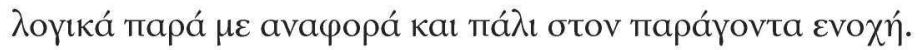

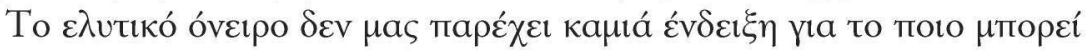

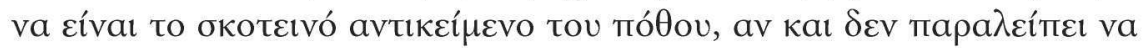

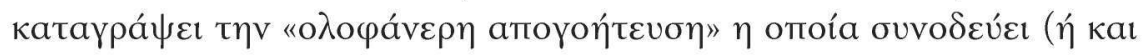

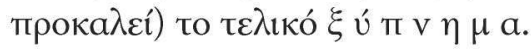

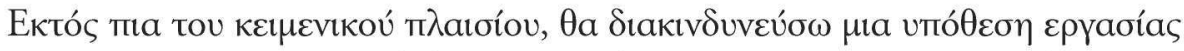

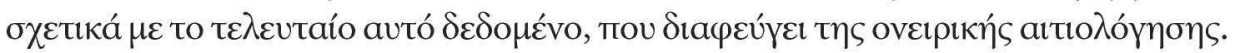

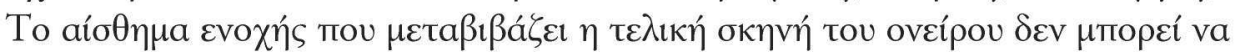

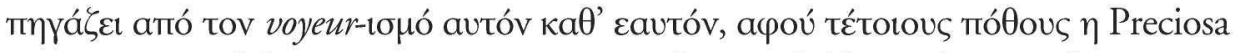

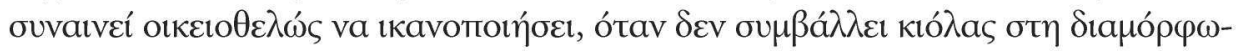

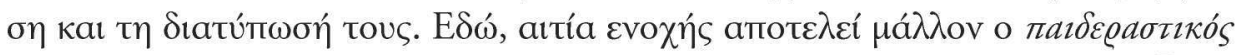

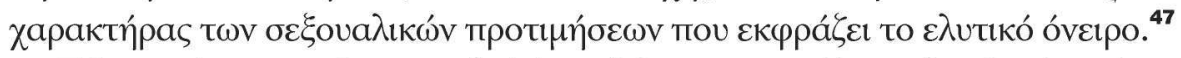

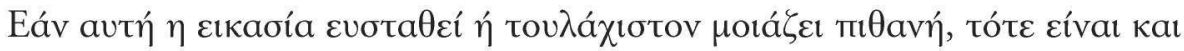

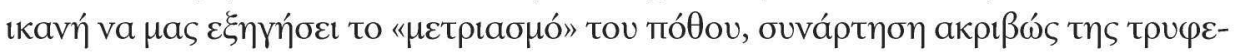

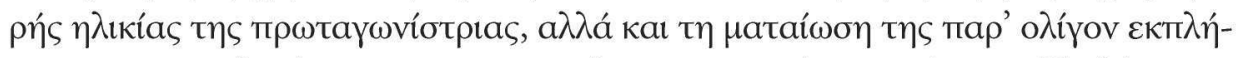

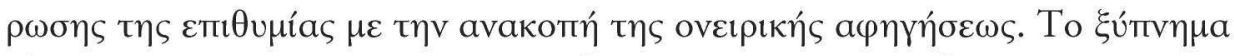

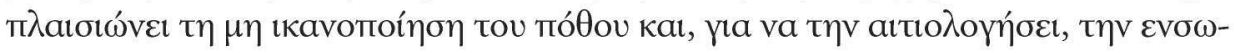




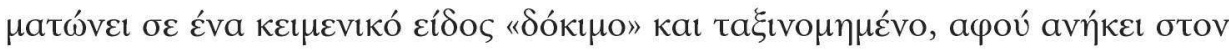

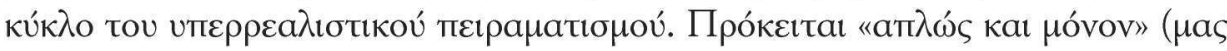

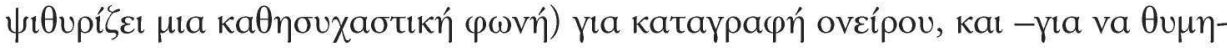

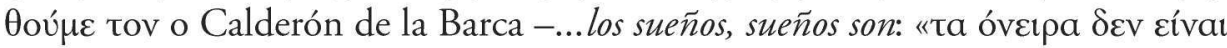

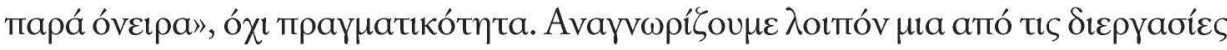

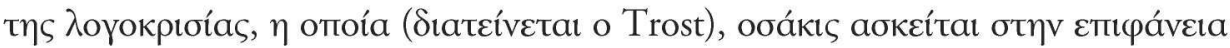

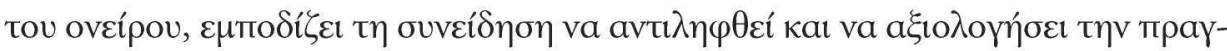

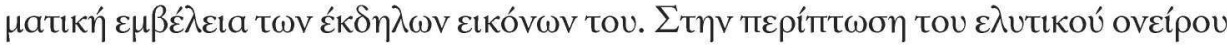
таро́

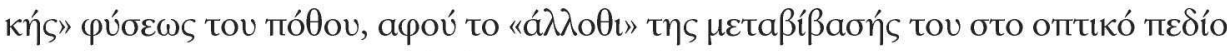

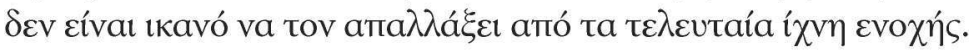

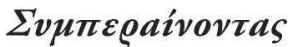

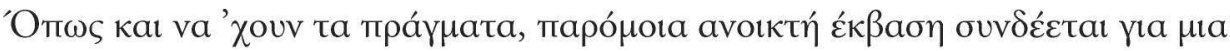

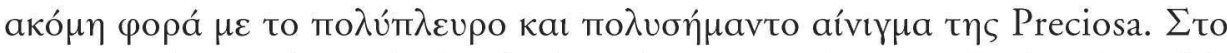

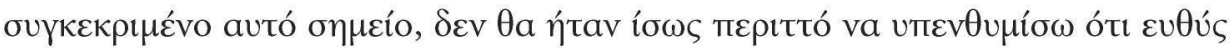

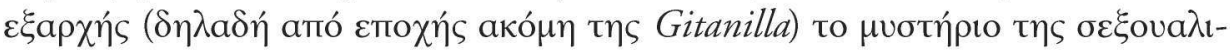

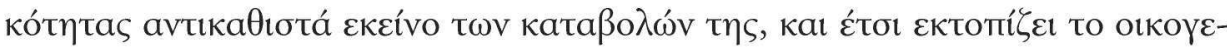

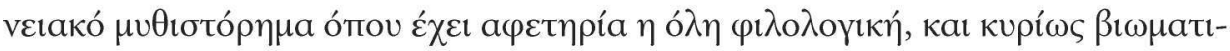

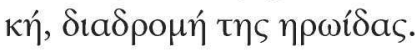

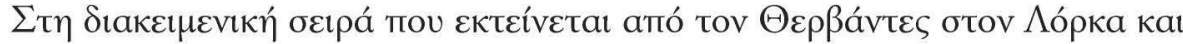

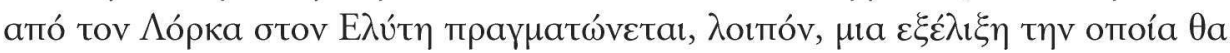

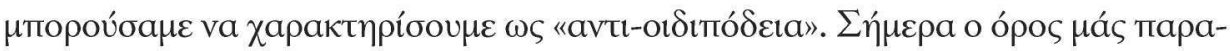

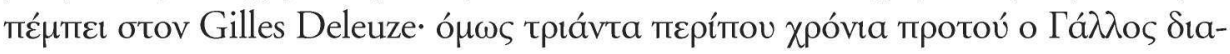

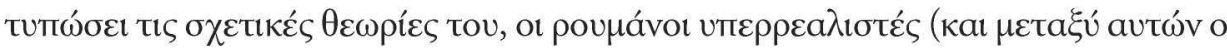

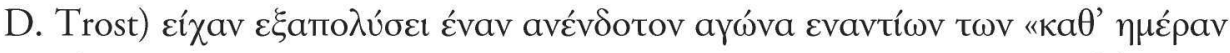

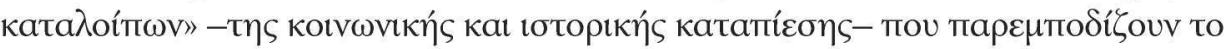

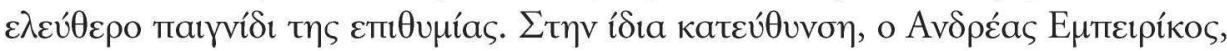

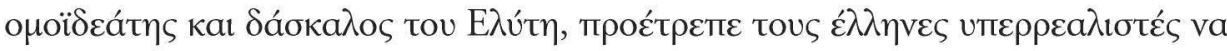

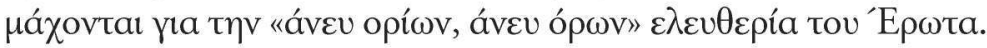

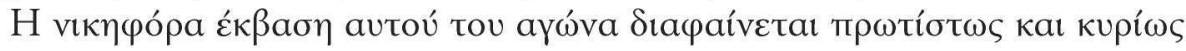

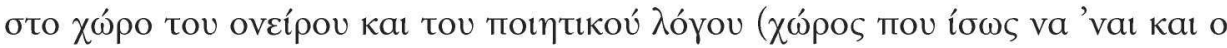

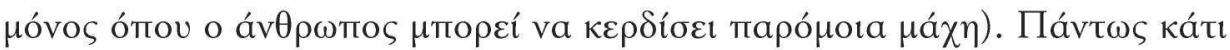

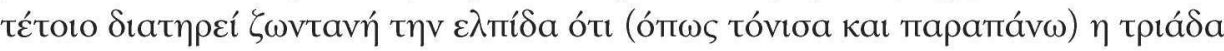

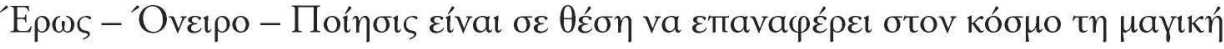

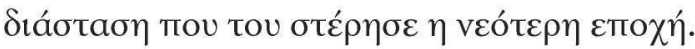




\section{$\Sigma$ H M E I $\Omega \Sigma E I \Sigma$}

$1 \Pi \rho \beta$. Victor Ivanovici, «Preciosa y su prenda tan preciada (una lectura de $L a$ Gitanilla)», бтov tó o Alicia Villar Lecumberri ( $\varepsilon \pi \mu \varepsilon \lambda$.$) , Cervantes en Italia.$ Décimo Coloquio Internacional de la Asociación de Cervantistas, Asociación de Cervantistas, Palma de Mallorca 2001, бo. 213-227.

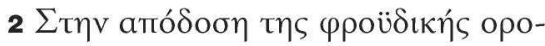

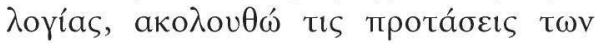

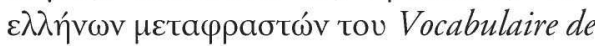
la Psychanalyse $\tau \omega \mathrm{v}$ Jean Laplanche кaı J.-

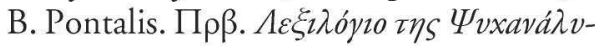

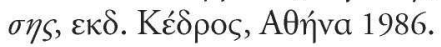

3 Harold Bloom, The Anxiety of

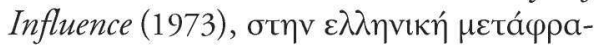

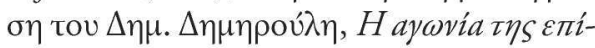

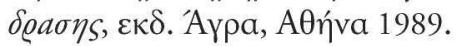

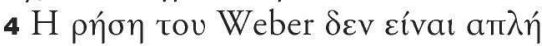

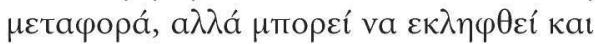

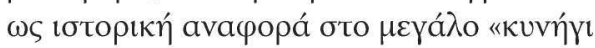

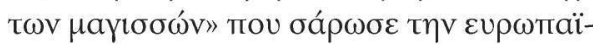

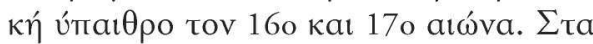

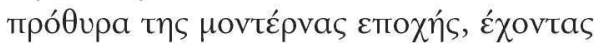

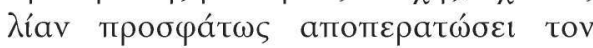

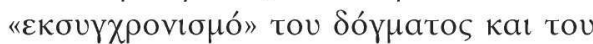

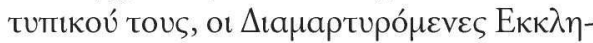

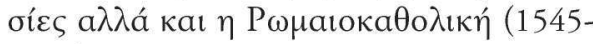

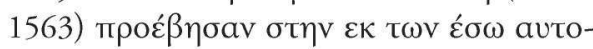

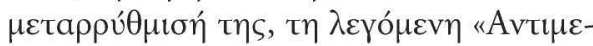

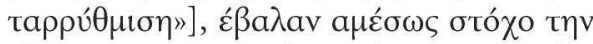

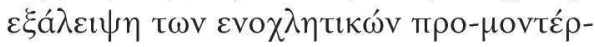

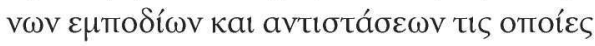

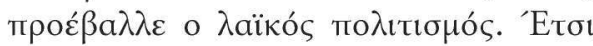

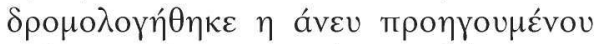

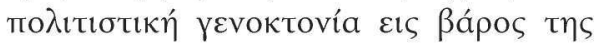

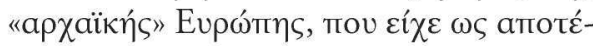

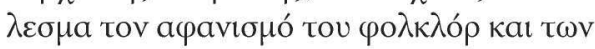

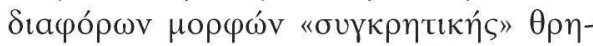

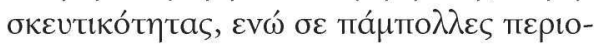

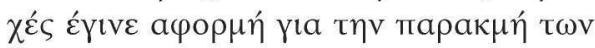

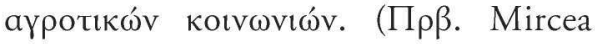
Eliade, Histoire des croyances et des idées religieuses, $\varepsilon \kappa \delta$. Payot, Парíot 1983, \$306).

5 Пр $\beta$. Octavio Paz, Los hijos del limo. Del romanticismo a la vanguardia, $\varepsilon \kappa \delta$.

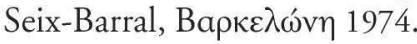

6 D. Trost, «Le même du même»

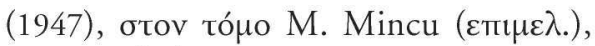
Avangarda literar româneasc. [Pouнavıќ

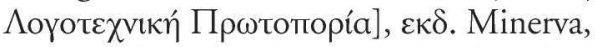

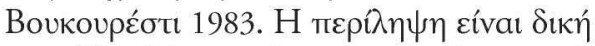

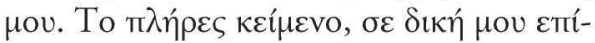

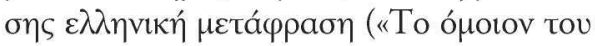

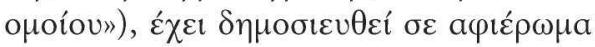

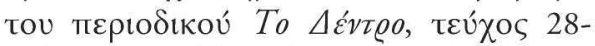

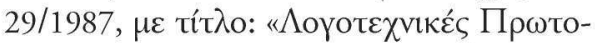

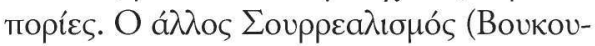

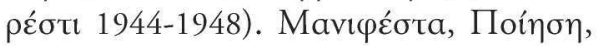

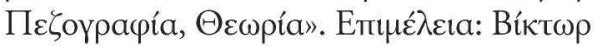

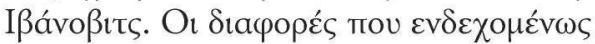

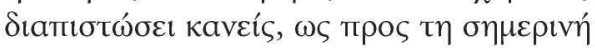

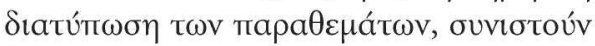

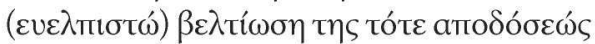

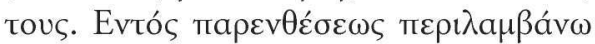
ка́тогєৎ троо

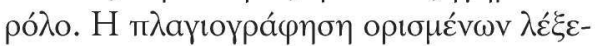

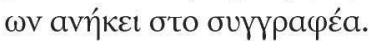

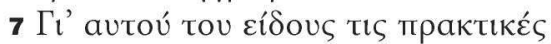

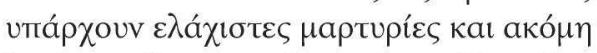

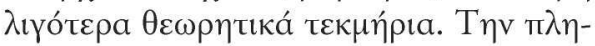

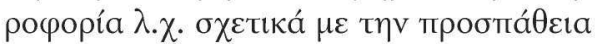

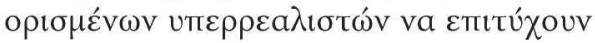

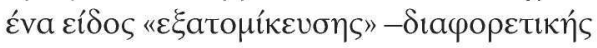
ó $\mu \omega \varsigma$ aто́ to Individuationsprozess tou

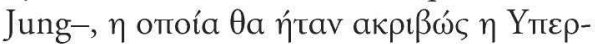

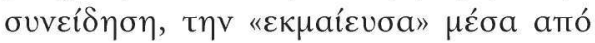

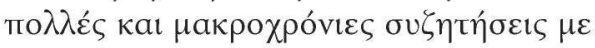

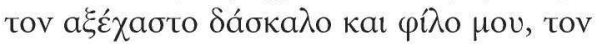

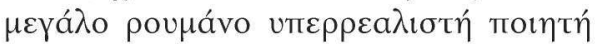
Gellu Naum (1915-2001). 


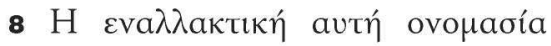

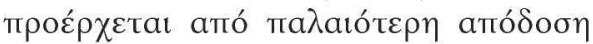

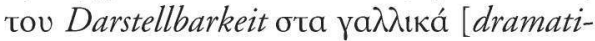

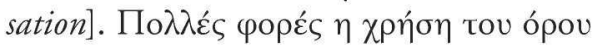

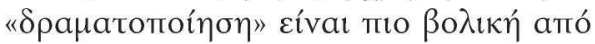

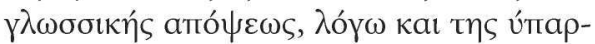

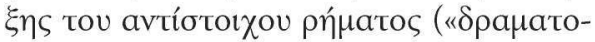

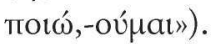

9 Federico García Lorca, "Preciosa y el aire» / Romancero gitano (1928), кaı

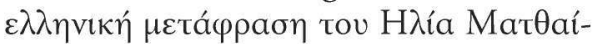

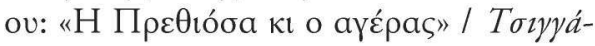

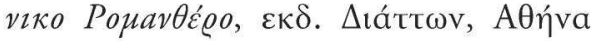

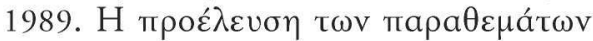

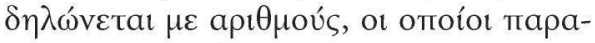

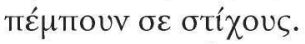

$10 \Pi \rho \beta$. Albert B. Lord, The Singer of Tales, Cambridge, Massachusetts 1960, $\sigma$. 30 каı ак.

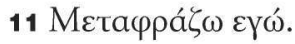

$12 \Pi \rho \beta$. Sigmund Freud, Le rêve et son

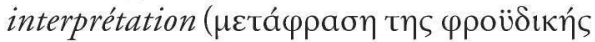

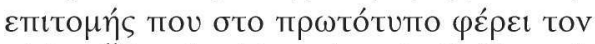

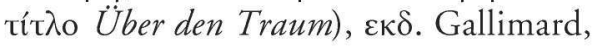

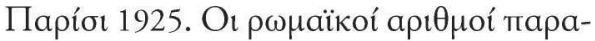

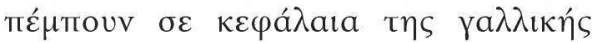
$\varepsilon \kappa \delta \delta ́ \sigma \varepsilon \omega \varsigma$.

$13 \Omega$ ऽóoo, o Guillermo Díaz Plaja,

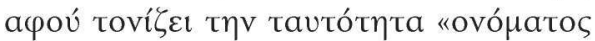

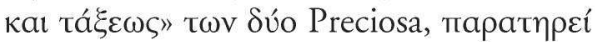

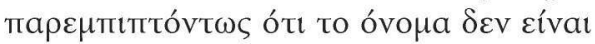

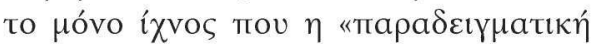

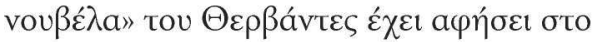
Romancero gitano ( $\chi \omega \rho$ pís ó $\mu \omega \varsigma$ канía

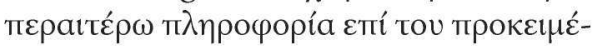
vov), Прß. G. Díaz Plaja, Federico García

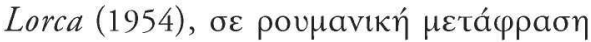
tou Virgil Athanasiade, $\varepsilon \kappa \delta$. Univers, Bov-

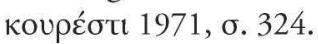

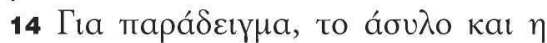

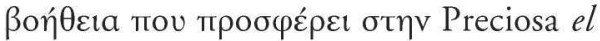

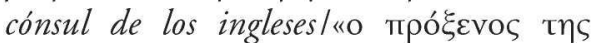

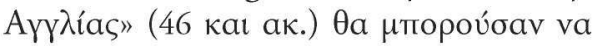

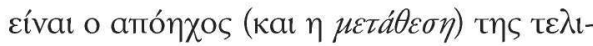

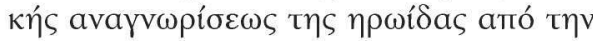

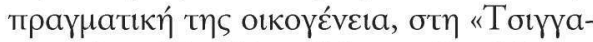

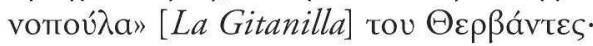

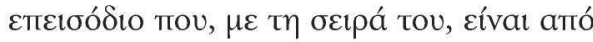

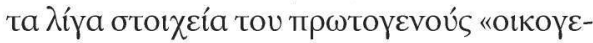

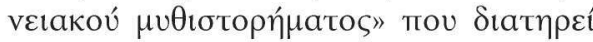

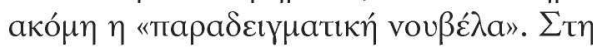

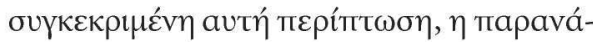

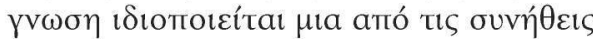

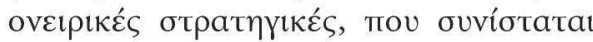

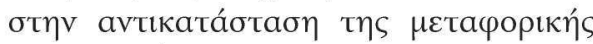

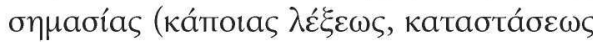

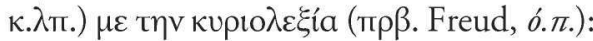

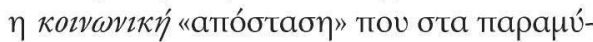

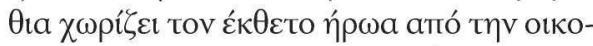

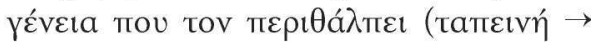

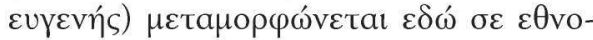

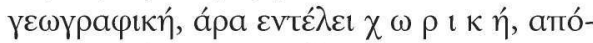

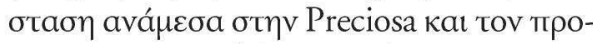

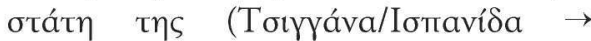

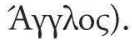

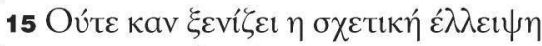

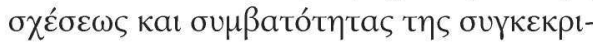

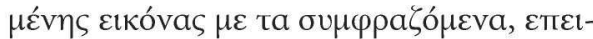

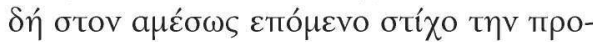

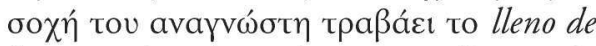

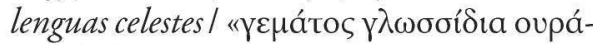

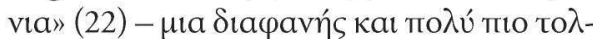

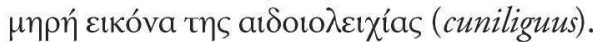

16 Miguel de Cervantes Saavedra, La Gitanilla, en Novelas ejemplares (1613),

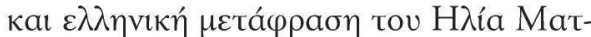

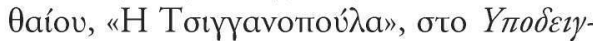

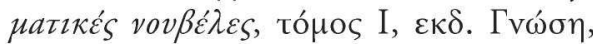
AӨฑ́va 1989, б. 88.

$17 \Delta \varepsilon v$ cíva tᄁ

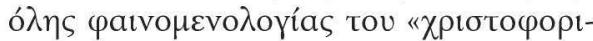

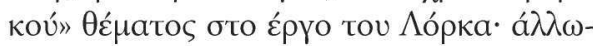

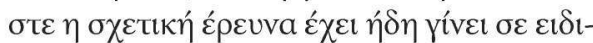

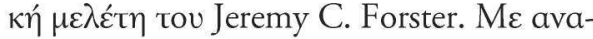

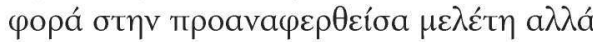

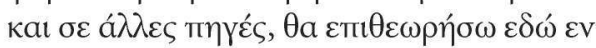




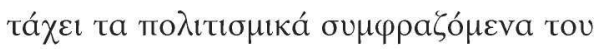

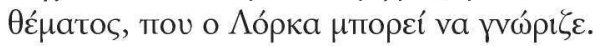

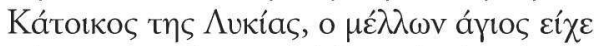

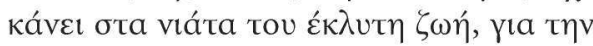

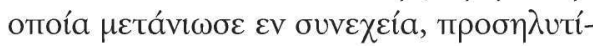

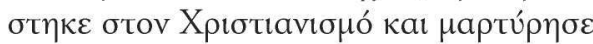

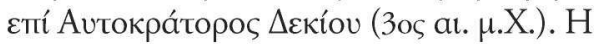

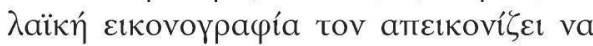

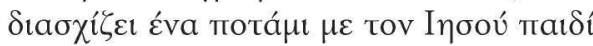

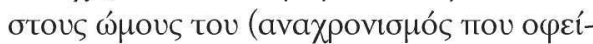

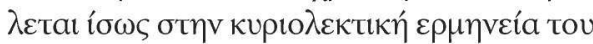

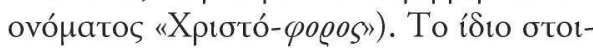

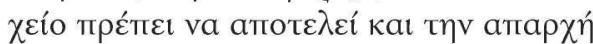

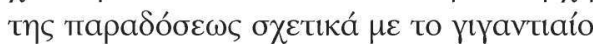

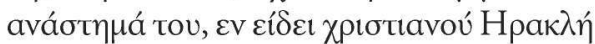

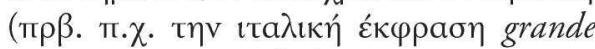

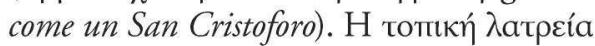

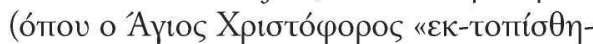

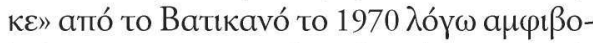

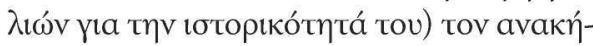

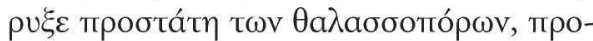

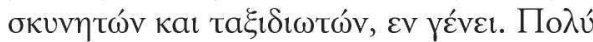

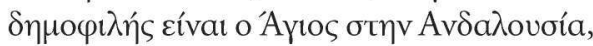

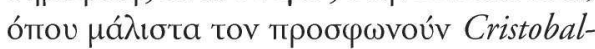

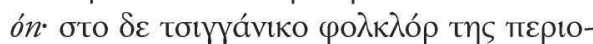

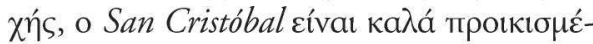

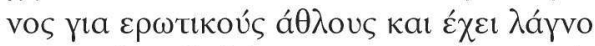

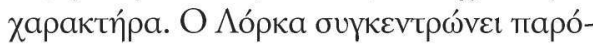

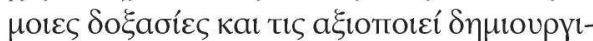

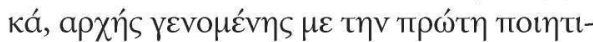

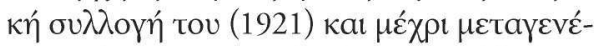

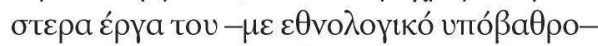

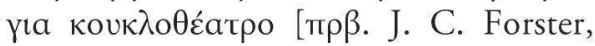
"Aspects of Lorca's Saint Christopher", oto Bulletin of Hispanic Studies, XLIII (1966),

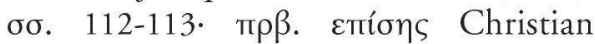
Ionescu, Mică enciclopedie onomastică

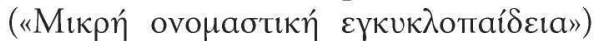

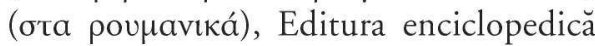

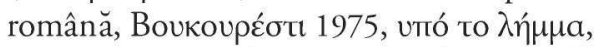
кaı Diccionario básico Espasa (15 тó 10 ),

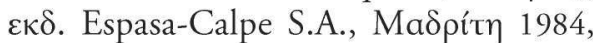

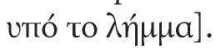

$18 \Pi p \beta$. A. Lord, ó.л. б. 37.

$19 \Pi \rho \beta$. Freud, ó.n., IV.

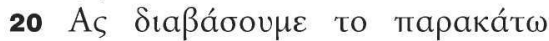

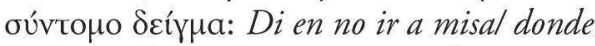
hubiese el ángel/que venciendo pintan/ sierpes infernales./Viendo a San Cristóbal/ forma de gigante,/ me dieron mil veces/ desmayos mortales./ Nunca he visto toros,/ de miedo que salten (...) / «Mov' $\rho \theta \varepsilon \eta \lambda$ ó $\xi a$

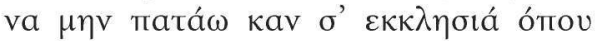

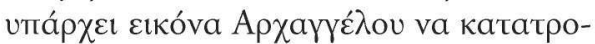

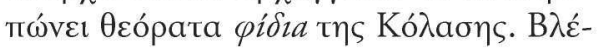

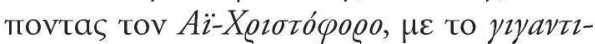

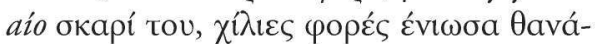

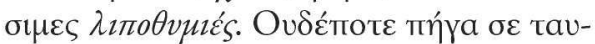

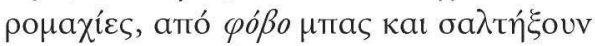

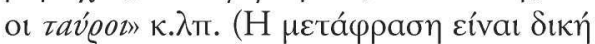

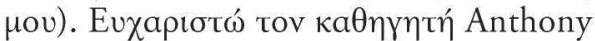

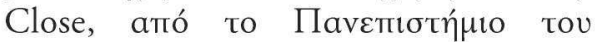

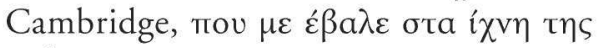

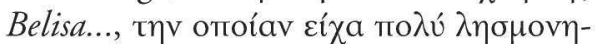

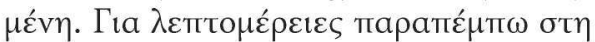

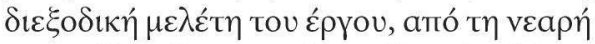

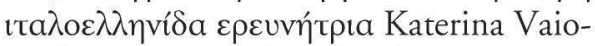
poulos, "Los melindres de Belisa: comicità e

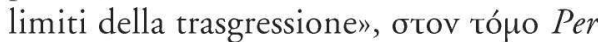
ridere. Il comico nei Secoli d'Oro, Alinea

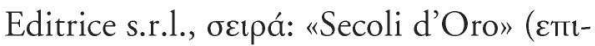

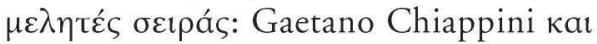

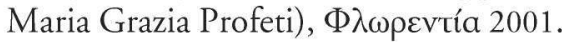

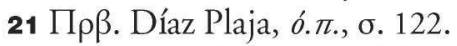

22 A poú, кatá tov Freud (ó.n., IV),

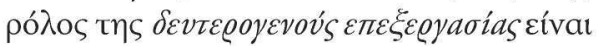

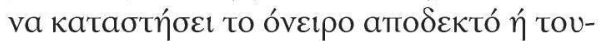

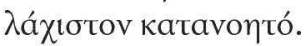

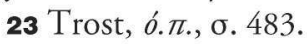

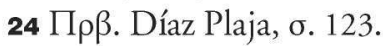

$25 \Delta$ tó̀ou tuxaía, Preciosa y el aire a

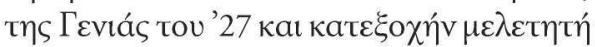

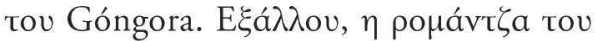

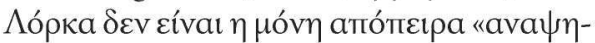

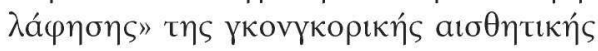




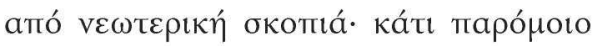

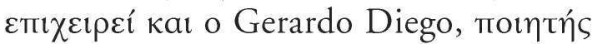

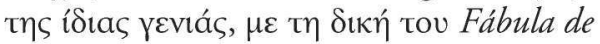

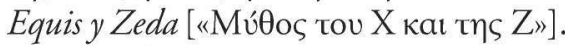

26 Federico García Lorca, «La imagen poética de Don Luis de Góngora», otov тó

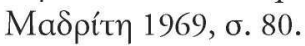

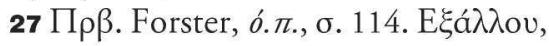

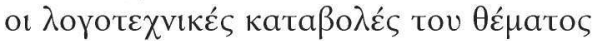

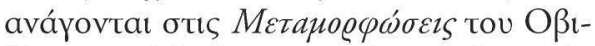

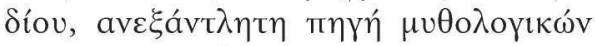

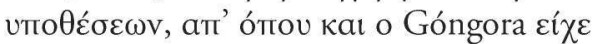

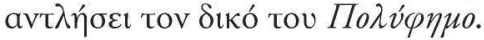

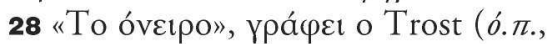

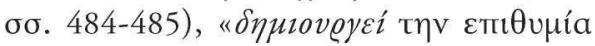

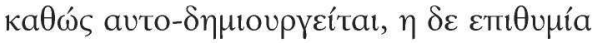

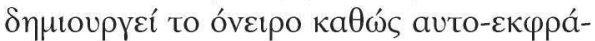

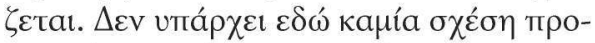

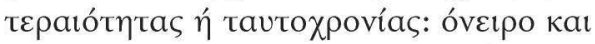

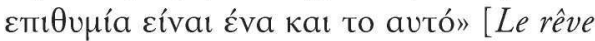
crée le désir en se créant lui-même, le désir crée le rêve en s'exprimant. Il n'y a ici nul rapport d'antériorité ou de simultanéité: rêve et désir se confondent].

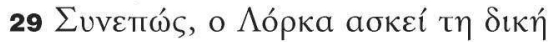

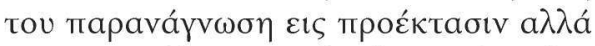

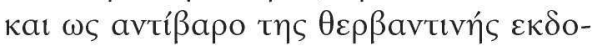

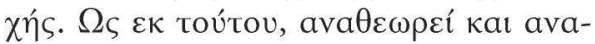

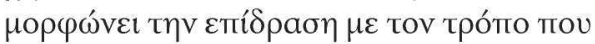

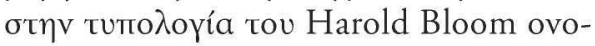

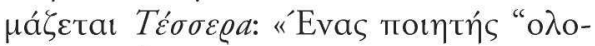

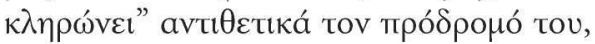

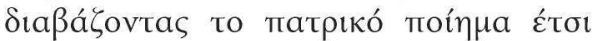

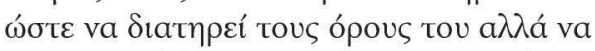

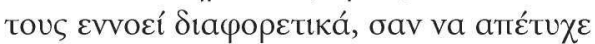

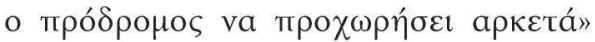
(Bloom, ó.n., o. 51).

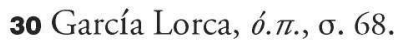

31 García Lorca, «El Cante jondo (Primitivo canto andaluz)", бто Obras

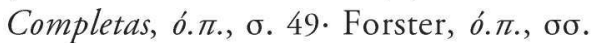
110-111.

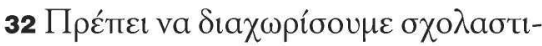

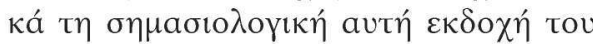

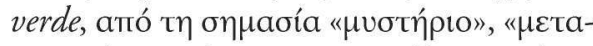

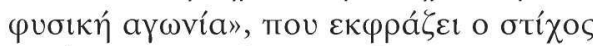
verde viento, verdes ramas / "трáotva $\kappa \lambda$ a-

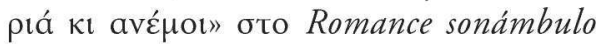

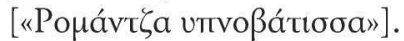

3з П $\beta$. Gaston Bachelard, L'air et les

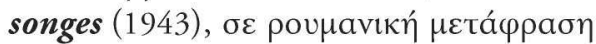

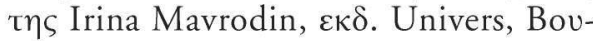

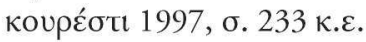

34 García Lorca, «La imagen...», ó.r., б. 81.

35 Díaz Plaja, ó.n., o. 123.

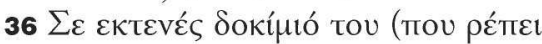

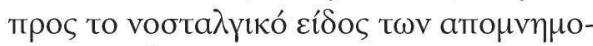

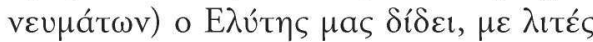

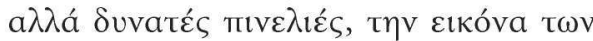

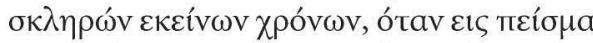

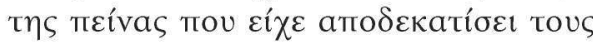

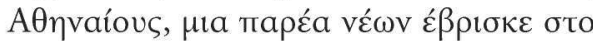

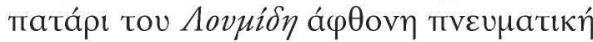

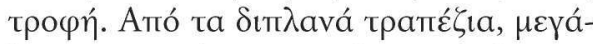

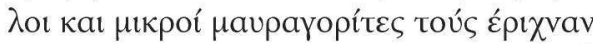

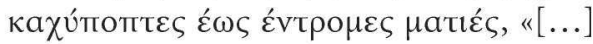

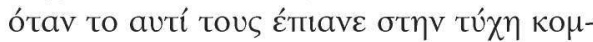

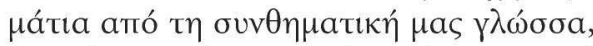

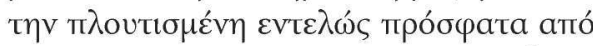

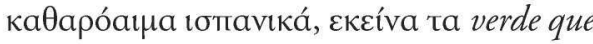
te quiero verde, каı ' ' á $\lambda \lambda a$, та тьо $\varepsilon \lambda \kappa v-$

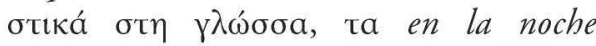
platinochel noche, que noche nocheras (OSvo-

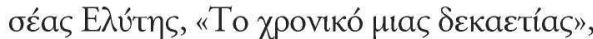
бтоv тó A日ŕva 1974, о. 399).

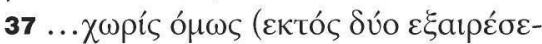

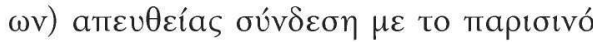
ке́vтро tou Kıvท́uatos.

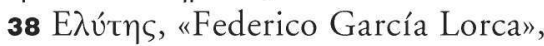
ó.r., б. 631.

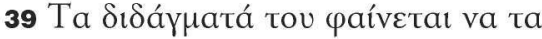

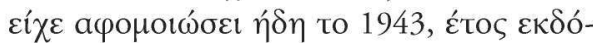

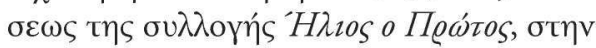




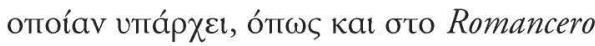

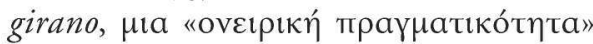

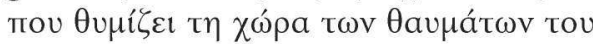

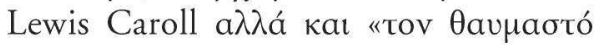

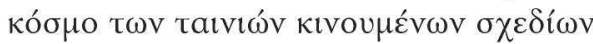

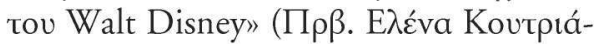

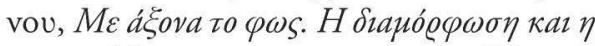

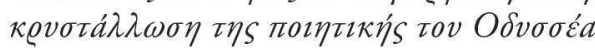

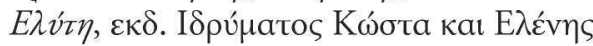

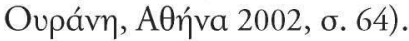

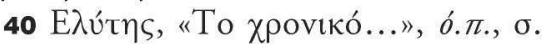
378.

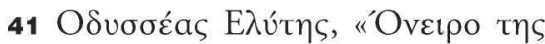

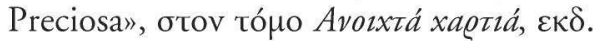

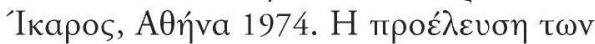

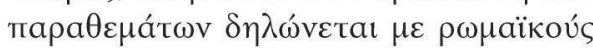

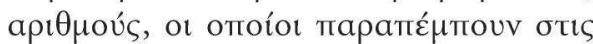

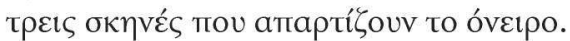

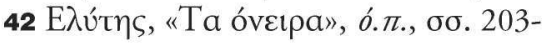
207.

43 Trost, ó. $\pi .$, б. 488.

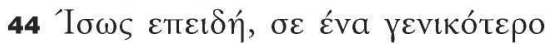

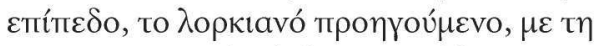

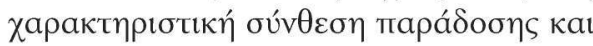

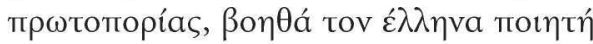

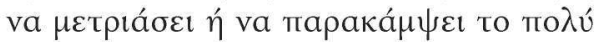

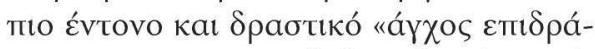

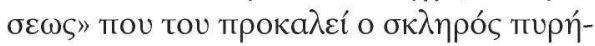

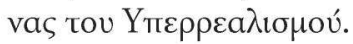

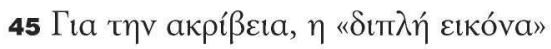

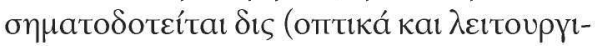

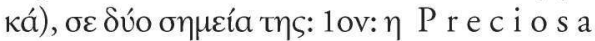

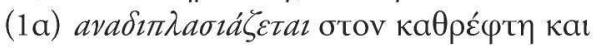

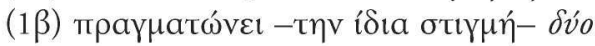

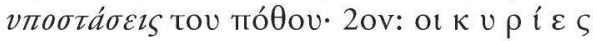

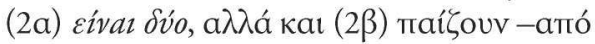

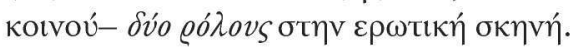

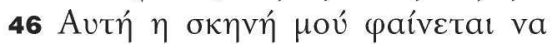

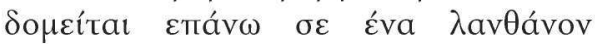
calembour, aт' autá тоu avapúovtaı avá

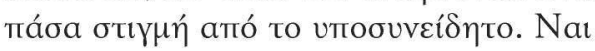

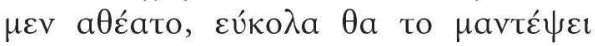

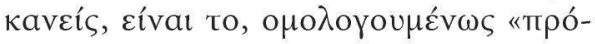

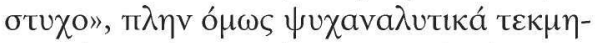

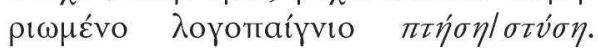

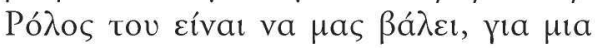

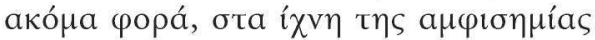

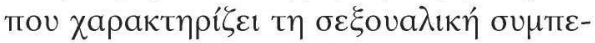

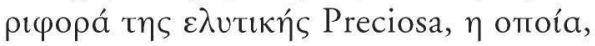

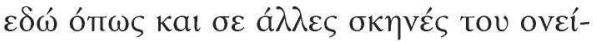

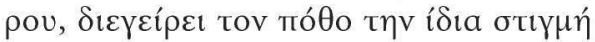
тои тоу икауотовєі́.

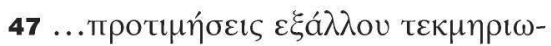

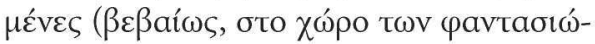

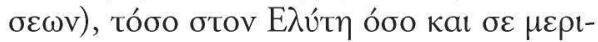

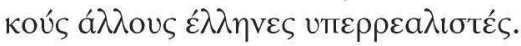

\section{S O M M A I R E}

\section{Victor IVANOvici: Rêver à Preciosa/rêver de Preciosa}

C et essai constitue la suite de Preciosa y su prenda tan preciada («Preciosa et son bijoux si précieux»), communication que j'ai lue au Dixième Colloque International de la Société des Cervantistes (Rome, 27-29 septembre 2001).

Là, j'étudiais les rapports de filiation entre La Gitanilla de Cervantès et certaines narrations mythiques et folkloriques qui s'ajustent au scénario psychanalytique nommé par Freud "roman de famille" [Familienroman]. L'une des hypothèses envisagées dans la communication respective était que la «nouvelle exemplaire» de Cervantès y le «roman de famille» forment d'emblée un intertexte onirique. 
Ici je me propose de mettre à preuve mon hypothèse par rapport à deux autres échantillons. Le premier est une romance de Federico García Lorca, où le chantre de Grenade rêve à "Preciosa" -l'ouvrage de Cervantès-, dans le contexte de son propre Romancero gitano. Le second est un texte en prose, présenté explicitement comme transcription d'un rêve ; son auteur, le poète grec Odysseas Elytis, rêve de Preciosa (le personnage) à partir du point précis où s'achève la rêverie de Lorca.

L'intertexte onirique, ainsi amplifié, dépasse largement le texte de référence, tant dans l'espace que dans le temps. D'un côté, il va bien plus loin que Cervantès dans la dissimulation du «roman de famille», en ce sens que l'attraction de la figure féminine découle de moins en moins du secret de ses origines et de plus en plus du mystère de sa sexualité. D'un autre côté, les échantillons ci-dessus mentionnés appartiennent tous les deux au domaine de l'avant-garde littéraire du vingtième siècle, où une nouvelle manière de rêver est en vigueur. 